\title{
CAPITAL INCOME FLOWS AND THE RELATIVE WELL-BEING OF AMERICA'S AGED POPULATION
}

\author{
Barry P. Bosworth, Gary Burtless, and Sarah E. Anders* \\ CRR WP 2007-21 \\ Released: December 2007 \\ Draft Submitted: October 2007
}
Center for Retirement Research at Boston College
Hovey House
140 Commonwealth Avenue
Chestnut Hill, MA 02467

Tel: 617-552-1762 Fax: 617-552-0191

http://www.bc.edu/crr

* Barry P. Bosworth is a Senior Fellow at The Brookings Institution. Gary Burtless is the John C. and Nancy Whitehead Chair in Economic Studies at The Brookings Institution. Sarah E. Anders is a senior research assistant at The Brookings Institution. The opinions and conclusions expressed are solely those of the authors and should not be construed as representing the opinions or policy of SSA, any agency of the Federal Government, The Brookings Institution, or Boston College. The authors would like to gratefully acknowledge the research assistance of Antung Liu.

(C) 2007, by Barry P. Bosworth, Gary Burtless, and Sarah E. Anders. All rights reserved. Short sections of text, not to exceed two paragraphs, may be quoted without explicit permission provided that full credit, including $\odot$ notice, is given to the source. 


\title{
About the Center for Retirement Research
}

The Center for Retirement Research at Boston College, part of a consortium that includes parallel centers at the University of Michigan and the National Bureau of Economic Research, was established in 1998 through a grant from the Social Security Administration. The Center's mission is to produce first-class research and forge a strong link between the academic community and decision makers in the public and private sectors around an issue of critical importance to the nation's future. To achieve this mission, the Center sponsors a wide variety of research projects, transmits new findings to a broad audience, trains new scholars, and broadens access to valuable data sources.

\author{
Center for Retirement Research at Boston College \\ Hovey House \\ 140 Commonwealth Avenue \\ Chestnut Hill, MA 02467 \\ phone: 617-552-1762 fax: 617-552-0191 \\ e-mail: crr@bc.edu \\ www.bc.edu/crr
}

\author{
Affiliated Institutions: \\ American Enterprise Institute \\ The Brookings Institution \\ Center for Strategic and International Studies \\ Massachusetts Institute of Technology \\ Syracuse University \\ Urban Institute
}




\begin{abstract}
One way to assess the effectiveness of a nation's pension system is to measure its success in bringing the incomes of the aged close to those enjoyed by the nonaged. The comparability of income estimates for the aged and nonaged depends, however, on the relative accuracy of the income reports for the two populations. Unfortunately, some income items that are particularly important to the elderly, including occupational pensions, income derived from financial assets, and returns on homeowners' net equity in their principal residence, are either unreported or significantly underreported in household surveys. In this paper we assess the effects of unmeasured and underreported income flows on the relative incomes of the aged and near-aged. We use survey data from the March Current Population Survey and the Survey of Consumer Finances. The latter survey contains information on wealth holdings as well as income. Using our broadest definition of income, which includes the return on net equity in an owneroccupied home and the predicted annuity flow from a household's financial assets, the incomes of aged households in the middle of the old-age income distribution appear to be similar to those of nonaged households in the middle of the nonaged income distribution. In the top and bottom one-quarter of the old-age income distribution, incomes under the broadest income definition are substantially higher than those of nonaged households in the equivalent position of the income distribution. This income pattern diverges sharply from the one that would be inferred under the Census Bureau's standard money income definition, which shows that aged households have noticeably lower incomes than the nonaged.
\end{abstract}




\title{
CAPITAL INCOME FLOWS AND THE RELATIVE WELL-BEING OF AMERICA'S AGED POPULATION
}

\author{
Barry P. Bosworth, Gary Burtless, and Sarah E. Anders
}

ONE WAY TO ASSESS the effectiveness of a nation's pension system is to measure its success in bringing the incomes of the aged close to the incomes received by nonaged adults. The comparability of income estimates for the aged and nonaged depends, however, on the relative accuracy of the income reports for the two populations. Unfortunately, some income items that are particularly important to the elderly, including occupational pensions and interest and dividend income, may be significantly underreported in household income surveys.

In 1990 the U. S. Census Bureau estimated that only 51 percent of the interest income and 33 percent of the dividend income in the National Income and Product Accounts (NIPAs) was reflected in the Current Population Survey (CPS) (U.S. Bureau of the Census 1993, pp. C-12 - C-13). In a more recent paper, Ruser and others (2004) found that using comparable income definitions the CPS captured only about two-thirds of NIPA-reported interest and dividend income in 2001. Since the aged are more likely than the nonaged to receive interest and dividend income, the understatement of these income components in a survey can bias our estimate of the relative position of the aged. The validity of the CPS reports of non-social security pensions has also been called into question (Schieber 1995 and Woods 1996). Defined-contribution pensions represent a major challenge to accurate measurement of the relative position of the aged. Many workers accumulate retirement savings that they do not convert into an annuity when they retire. Instead, retirees make phased withdrawals from their retirement savings in order to support consumption in old age. A large portion of these withdrawals are not reported as income in the CPS, but they do allow many retired workers to pay for consumption in old age. Finally, one source of capital income missed in most household surveys is the flow of services from owneroccupied homes. Homeownership is higher among the aged than among nonaged adults, so the omission of this income flow is likely to cause an understatement of the relative well-being of the aged.

In this paper we assess the effects of unmeasured and underreported income flows on the relative incomes of the aged and near-aged. The first section considers the accuracy of "money 
income" estimates from two household survey files, the Census Bureau's CPS and the Federal Reserve Board's Survey of Consumer Finances (SCF). Income as reported in these surveys is compared to aggregate income totals recorded in the NIPAs. We first define money income in a way that is consistent in both the NIPAs and the household surveys, and we then document and try to account for the reporting differences in the three sources. We compare the distributions of money income reported on the CPS and SCF to see whether these two micro-survey files tell a consistent story about the relative income positions of households headed by aged and nonaged adults. In the second section we adjust the money income reported in the CPS to reflect some of the effects of underreporting on total household income. The adjustments eliminate about twothirds of effects of underreporting, including underreporting of capital income. The third section considers an important source of capital income that is not included in money income, namely, the flow of implicit income from owner-occupied housing. In our expanded definition of income we include Census Bureau estimates of this income item. In addition, we derive our own estimates of income flows from housing using respondents' reports of mortgage balances and housing wealth on the SCF. Including this income flow in the definition of income significantly improves the relative position of the elderly and of households in the bottom half of the income distribution. The fourth section of the paper considers how the relative income position of the elderly is affected if we convert households' defined-contribution pension holdings into an annuity income flow. Section 5 examines the implications of a more extreme adjustment in which we convert non-pension financial wealth into an annuity. In the final section of the paper we discuss implications of our findings for evaluating the relative living standards of the elderly.

We are not the first analysts to examine relative well-being under an alternative and broader measure of income. In recent years Wolff and Zacharias (2006) and Smeeding and Thompson (2007) have used wealth and income data in the SCF to derive broader estimates of well-being that include imputed income flows from wealth holdings. Wolff and Zacharias estimate trends in income under the standard Census Bureau definition of money income and under a "wealth adjusted measure" that includes imputed rent on owner-occupied homes plus estimated income flows when all non-housing wealth is converted into a life annuity. Their estimates show a sizeable improvement in the relative position of households headed by an aged person when the broader income measure is used. For example, among families headed by a person 75 or older, the standard money income definition shows that the median family income 
in 2001 was 52 percent below the median income received by all SCF households. Under the broader income measure, the median income of families with a head 75 or older was only 33 percent below the median income of all SCF households (Wolff and Zacharias 2006, p. 16). Not surprisingly, the change in the mean income position of older households using a broad income measure is even greater than the change in their median income position. Smeeding and Thompson (2007) define a series of "more complete income" definitions, which include imputed capital income flows from successively larger portions of households' financial and nonfinancial wealth holdings. They derive estimates of capital income flows by calculating the income a household would receive if its return on holdings in each asset category were the same as the economy-wide return on that asset. Although the authors are not primarily interested in how their income adjustments affect the relative income position of the aged, their results, like those of Wolff and Zacharias, show a large relative improvement in the position of households headed by the aged (Smeeding and Thompson 2007, Appendix Table 5).

Unlike these earlier analyses, our paper attempts to adjust income reports in the nation's most widely used source of data about the income distribution, the CPS. We find that the CPS provides reasonable though imperfect estimates of wage and transfer incomes, but we use income and wealth data from the SCF to improve and expand the estimates of capital income. Like Wolff and Zacharias (2006) and Smeeding and Thompson (2007) we find that the inclusion of better estimates of capital income flows has a substantial impact on the relative well-being of the aged.

Our basic findings can be summarized briefly. Using our broadest definition of income, which includes the return on homeowners' net equity in their principal residence and the predicted annuity flow from financial assets, the incomes of aged households in the middle of the old-age income distribution appear to be approximately the same as those of nonaged households in the middle of the nonaged income distribution. In the top and bottom quarters of the old-age income distribution, incomes under the broadest income definition are substantially higher than those of nonaged households in the equivalent position of the income distribution. This relative income pattern diverges sharply from the pattern inferred using the Census Bureau's standard money income definition. 


\section{Measuring Capital Income and Pensions in Household Surveys}

In recent years estimates of aggregate household income from the CPS have accounted for roughly 70-75 percent of total personal income recorded in the NIPAs. Some of the difference reflects measurement error and income underreporting in the CPS. However, much of the discrepancy is the result of conceptual differences in the definition of income between the CPS and the national accounts. The main CPS income definition ("money income") focuses on cash income directly received by households, a measure that is closely related to the income that would be reported on tax returns. The NIPA measure of (gross) personal income is much broader. An important difference is that the NIPA measure includes and the CPS measure excludes employer supplements to wages and salaries, such as contributions for employee health and pension plans as well as for social insurance. The NIPA estimate of personal income also includes the capital income that insurance carriers and noninsured pension plans receive in their

role as agents of households. For example, insurance companies receive interest, dividends, and rent payments as investment income on policyholders' reserves. This income is treated in the NIPAs as though it is a payment to households, even though survey respondents are largely unaware of this income and are not asked to report it on the CPS or SCF. The national accounts also impute to households the income that is implicitly earned as a result of home ownership, medical care financed through Medicare and Medicaid, and many financial services furnished without explicit charge by banks and financial intermediaries. Finally, the standard NIPA measure of personal income also includes the earnings of nonprofit institutions. Much or all of the NIPA-recorded income from these sources must be excluded to calculate income in a way that corresponds to the Census Bureau's definition of money income.

On the other hand, some income sources that are not regarded as part of personal income in the national accounts are included in the Census money income definition. Most important, money income excludes the flow of employer contributions in pension funds and the capital earnings of those accounts, but it includes the benefits that are paid out of many of the accounts. A similar treatment is applied to private insurance programs, such as private workers' compensation. In addition, the money income definition includes and the national accounts exclude inter-household transfers, such as alimony and child support.

Deriving money income benchmarks from the NIPAs. We have made adjustments to the NIPA estimate of personal income to align it more closely with the concept of money income 
used in the CPS. The adjustments are summarized below and described in some detail in Appendix A. Our procedures are based on important prior contributions by Woods (1996), Roemer (2000), and Ruser et al. (2004). Figure 1 compares adjusted and unadjusted measures of personal income from the NIPAs with our estimates of total money income reported in the CPS. These estimates cover income received in calendar years 1988 through 2005. The top line shows the trend in aggregate personal income as defined and recorded in the NIPAs. A lower line shows NIPA estimates of money income under the Census Bureau's money income definition. The CPS-based estimate of money income is consistently below the adjusted measure from the national accounts, but the difference appears to be relatively stable over time. Between 1988 and 2004 money income reported on the CPS represented about 88 percent of the adjusted personal income recorded in the NIPAs. ${ }^{1}$ The figure also compares the NIPA and CPS income estimates to estimates of money income based on six of the SCF surveys, covering income received every third year between 1988 and 2003. The reporting of income on the SCF is more volatile, but its estimate of money income averages about 98 percent of the equivalent NIPA measure, and it is consistently above the estimate from the CPS.

The CPS concept of wage and salary income is very similar to that in the national accounts with one important exception. The CPS classifies income from Subchapter S corporations as wage and salary income, while in the NIPAs Subchapter S corporate income is included in corporate profits and passed through as dividend income received by individuals (Ruser et al. 2004). In 2005, Subchapter $S$ corporate income is estimated at $\$ 355$ billion or about 6 percent of wage and salary income. We are uncertain whether the Census Bureau is successful in ensuring that $\mathrm{S}$ corporation income is classified as wages and salaries rather than as selfemployment income or capital income on the CPS. Nonetheless, we reclassified the NIPA data to match the intended treatment in the CPS. Minimal adjustments, primarily to remove the capital consumption adjustment from the NIPA estimate, are required for self-employment income. The principal difference between the NIPA and Census money income definitions of transfer income is that the NIPA definition includes non-cash transfers, such as Medicaid and

\footnotetext{
${ }^{1}$ We use the public-use versions of the CPS files, and these files are affected by the Census Bureau's topcoding procedures. Prior to 1996, incomes above the top-code value were recorded at the limit. Since 1996, the income of top-coded individuals is replaced by the mean reported income of respondents with incomes above the limit.
} 
Medicare benefits and food stamps. In recent years these benefits have accounted for between 9 and 10 percent of NIPA personal income, or almost $\$ 1$ trillion.

The more difficult definitional differences between the NIPA estimates and the CPS definition of money income are associated with capital income (interest, dividends, and rents) and pension income. Many of these differences arise because the NIPAs include financial accounts managed for households - primarily pension and insurance funds - as part of the household sector. Thus, employer contributions to pension plans are part of labor compensation, and the capital income and rents earned by the funds are included as part of personal income received by households. In contrast, the CPS collects information on cash benefit payments received by households, including the benefits paid by defined-benefit pension funds. As a rule, survey respondents have little knowledge about the income earned on their behalf by fiduciaries. In order to adjust the NIPA capital income estimates so they conform to the Census Bureau concept of money income, we excluded several income items that the national accounts include as part of capital and rental income. The excluded items are the capital income and the capital consumption adjustment of life insurance and pension plans, the capital income received by nonprofit institutions, the dividends paid by Subchapter S corporations, and several forms of imputed income (mainly the value of services provided for free by financial institutions). These definitional adjustments eliminate nearly three-quarters of the capital income that is included in the NIPA measure of personal income.

The most problematic adjustment to the NIPAs involves the estimate of the payouts from funded pension plans. This is not straightforward because there is no aggregate estimate of pension benefit payments, either in the NIPAs or any other official source, that matches exactly the concept of money income used in the CPS. In the NIPAs, income is credited to households when it flows into the pension plan. Thus, employee contributions to pension plans are included in the NIPAs as part of "wage and salary disbursements," and employer contributions are counted as "other labor income." Since pension and annuity payments are viewed as a transaction that takes place within the household sector, they are not an identified component of personal income in the national accounts. The technical issues are discussed in detail by Woods (1996), and some of the basic conceptual issues are discussed by Ruser et al. (2004).

The NIPAs provide supplementary information that can be used to construct benchmark estimates for government employee pension benefits, but for a number of reasons the national 
accounts lack good information on regular benefits paid by private pension plans. The data are not adequate to distinguish regular monthly or quarterly payments from lump-sum distributions (Woods 1996). While the former count as money income in the CPS, the latter do not. Instead of using the NIPAs, we have used the estimate of pension and annuity payments from the IRS Statistics of Income (SOI) files as the national estimate that is most compatible with the concept of money income in the CPS.

We have used similar procedures to align the income estimates of the SCF with the CPS concepts. However, the SCF has considerably fewer questions on sources of income and focuses on collecting information within a few broad aggregates. In addition, a change in the SCF questionnaire in 2004 to link some answers to specific lines of respondents' income tax returns greatly altered the pattern of responses. The only conceptual change is that Subchapter S corporate income is included with self-employment income rather than wages and salaries. ${ }^{2}$

Household survey income reports compared to the NIPAs benchmarks. Table 1 shows our estimates of the percentage of benchmark money income that is reported in the CPS and SCF files. The estimates cover the six years between 1988 and 2003 for which income data were collected in the SCF. We have divided income into four broad categories - earned income, capital income, government cash transfers, and pensions. Over the six years shown, earned income, including dividend payments of Subchapter S corporations, accounted for about 80 percent of benchmark money income. A large proportion of this income is reported on both the CPS and SCF, with a higher proportion reported on the SCF. The percentage gap is particularly striking in the case of self-employment income, where between 40 percent and 54 percent of the net self-employment income shown in the NIPAs goes unreported on the CPS. We find it remarkable that the SCF records a higher level of wage income than the CPS. As noted above, the SCF wage measure does not include Subchapter S corporate income, which represents about 0.5 percent of the benchmark wage measure. The SCF also finds a much higher level of selfemployment income, at least until 2003 when a change in the SCF questionnaire led to a large shift of self-employment income into capital income.

\footnotetext{
${ }^{2}$ In the 2004 SCF a change was implemented to point individuals directly to the relevant line 17 of tax form 1040. Compared with responses in 2001 and earlier years, the 2004 SCF shows a substantial shift of income away from self-employment and into capital income. This change in response patterns suggests that many SCF respondents included their Subchapter S corporate income in self-employment income before 2003. Few SCF respondents seem to have believed that Subchapter $\mathrm{S}$ corporation income was equivalent to wage income.
} 
A larger proportion of capital income is also reported in the SCF than in the CPS. Curiously, however, a larger percentage of CPS households reports receiving several forms of capital income. In 2000, for example, 58 percent of CPS households compared with just 29 percent of SCF households reported receiving interest income. One-quarter of CPS households reported receiving dividends, while only 17 percent of households in the SCF reported receipt of dividends. When compared with the adjusted NIPA money income benchmark, capital income reporting in both the CPS and SCF is quite erratic. Capital income is usually underreported on the CPS and overstated on the SCF, but the percentage gap between the household survey estimate and the NIPA benchmark varies over time. We believe some of the variability occurs because of changes in the wording or order of income questions and because of respondents' uncertainty about the correct classification of some income items. The income payment from a bond is classified as interest, for example, while income payments from a bond mutual fund are classified as dividends. The variability of SCF responses highlights many of the ambiguities of relying on survey respondents to distinguish between self-employment income and various sources of capital income. ${ }^{3}$ Capital income reported in both the CPS and SCF surveys has risen erratically over time in comparison with the benchmark NIPA estimate of capital income.

Government cash transfer payments, which account for about $8 \frac{1}{2}$ percent of benchmark money income, are comparatively poorly reported on both the CPS and the SCF. In this case, however, the income reports in the CPS come closer to matching the NIPA money income benchmark than the reports in the SCF. For aged Americans the most important source of government cash transfers is Social Security Old-Age, Survivors, and Disability Insurance (OASDI). Compared with most other types of transfers, a high proportion of OASDI benefits is reported on both the CPS and SCF. Other sources of transfer income, which are more important for the nonaged population, are less well reported in both surveys. This pattern of underreporting is likely to yield an understatement of the relative incomes of low-income and working-age respondents rather than aged respondents. The understatement is larger and less stable in the SCF than the CPS. This difference between the two surveys is almost certainly the

3 The surprisingly large overstatement of rent, royalty, and trust income shown in the SCF estimate for 2003 is probably due to a change in the questionnaire. Respondents were directed to a line in the Form 1040 which in turn referenced income reported on Schedule E. This supplementary form is used to report income from rental properties, Subchapter S corporations, some partnerships, and trusts. This is a very broad definition of capital income that, in addition to $\mathrm{S}$ corporation income, might have been viewed by some respondents as self-employment or business income. 
result of the SCF's focus on the accurate measurement of household wealth rather than household income.

According to both the NIPAs and the IRS Statistics of Income file, pension payouts represent a growing percentage of household income, whether income is measured using the NIPA concept of "personal income," the IRS estimate of "adjusted gross income," or the Census Bureau's concept of money income. What is unclear is the division of pension payouts between regular income payments and lump-sum distributions or rollovers into another retirement savings plan. If a growing fraction of payouts represents lump-sum distributions and rollovers, a shrinking share should be counted as regular money income. The tabulations in Table 1 suggest that a shrinking percentage of pension payouts reported in the Statistics of Income file is being reported in the CPS and SCF as pension benefits. ${ }^{4}$ We cannot be sure whether this reflects a growing misreporting problem on the two household surveys or a rise in the importance of rollovers and lump-sum distributions in the Statistics of Income.

The uncertainty is much lower in the case of military and public employee pensions, which consist almost entirely of regular cash payments rather than rollovers or lump-sum distributions (Woods 1996, p. 6, and Roemer 2000, pp. 65-66). Figure 2 shows the percentage of military and public employee pension payments recorded in the NIPAs that is reported on the CPS file. Only about 57 percent of the NIPA benchmark was reported on the CPS in 1988. By 2003 the amount reported on the CPS fell to 41 percent of the NIPA benchmark. The implied level of underreporting of government pensions is not far from our estimates of overall underreporting for pension income in the two years (see Table 1). Either set of pension-benefit estimates implies that income underreporting in the case of pensions is a more serious problem than for other major income sources. The shortfall in reported pension income will naturally produce a larger proportional effect on the reported incomes of the aged than the nonaged.

Relative money income of the aged and nonaged. Because income reporting patterns differ in the CPS and SCF it is likely that the relative income position of the aged and nonaged differs in the two surveys. To evaluate the income positions of the aged and nonaged we have divided households into three categories defined by the age of the head of household. We

4 There is a large increase in the reporting rate for pensions in the 2004 SCF. This may be related to a change in the questionnaire that pointed respondents to a specific line in the Form 1040. The 2004 SCF pension data exclude all IRA income, but they include taxable distributions (non-rollovers) from all pension and annuity accounts. 
classify households headed by a person who is under age 55 as "nonaged." Households headed by someone who is 55 to 64 years old are classified as "near-aged." Households with a head who is at least 65 years old are classified as "aged." Households that are headed by older adults tend to have fewer members, and this fact must be taken into account when measuring their relative income positions. One way to deal with differences in the number of household members is to estimate the change in income required to hold living standards constant when a household gets larger or smaller. In principle, such an adjustment allows us to calculate "equivalent" incomes for households of different sizes. A common adjustment, which we use here, is to assume that a household's income requirements increase in proportion to the square root of the number of household members. Formally, equivalent money income (EY) is equal to unadjusted household income $(\mathrm{Y})$ divided by household size $(\mathrm{S})$ raised to an exponential value $(e)$, that is, $\mathrm{EY}=\mathrm{Y} / \mathrm{S}^{e}$. Our assumption implies that the value of $e$ is $1 / 2 .^{5}$

To compare the incomes of people who live in nonaged, near-aged, and aged households, we first calculate the equivalent money incomes of all persons in the population. Figure 3 shows the size distribution of equivalent money income as measured in the CPS and SCF files measuring 2000 incomes. The chart shows the logarithm of equivalent money income at successive points in the income distribution. At the bottom of the income distribution, reported money incomes of persons in the CPS are higher than those of people in the SCF. At the $85^{\text {th }}$ percentile of each distribution, the equivalent incomes in the two surveys are identical. Above the $85^{\text {th }}$ percentile incomes are higher in the SCF survey than in the CPS survey. Table 1 shows that the SCF survey reports more money income than the CPS. Figure 3 shows the SCF also implies that there is a more unequal distribution of income.

In Table 2 we show how equivalent money income is distributed in the two surveys among people who are members of nonaged, near-aged, and aged households. The top panel displays estimates from the CPS; the lower panel, income estimates from the SCF. Average equivalent incomes and incomes at every position of the income distribution are measured as a percent of the median equivalent income in the CPS file. Note that the average equivalent income on the CPS is almost 30 percent higher than the median equivalent income estimated in

5 We chose $1 / 2$, a common value used in research on household income, because it represents the halfway point between two extreme assumptions about the economies of scale that individuals achieve when they live in larger households. 
the same file. The person on the CPS at the $5^{\text {th }}$ percentile receives an income that is slightly more than one-fifth of the median income in the CPS. ${ }^{6}$ The CPS respondent at the $95^{\text {th }}$ percentile receives 326 percent of the median CPS income.

The more interesting results show the relative income positions of people in nonaged, near-aged, and aged households. At the lowest positions in the equivalent income distribution, members of aged households fare somewhat better than members of households headed by a nonaged or near-aged person. That is, the $5^{\text {th }}$ percentile equivalent income for persons in aged households is about one-tenth higher than the $5^{\text {th }}$ percentile income received by nonaged or nearaged households. At higher ranks of the money income distribution, persons in aged households have substantially lower equivalent incomes than their counterparts in the nonaged and near-aged distributions. The median income received by people in aged households is about 72 percent of the overall median income. Among people in nonaged households, the median income is 104 percent of the overall median income, and among people in near-aged households it is 120 percent of the overall median. The mean income of people in aged households, shown in the right-hand column in Table 2, is also substantially lower than that received by people in nonaged or near-aged households.

Compared with incomes reported on the CPS, the income data in the SCF show lower real incomes in the bottom ranks of the distribution and higher incomes at the top. The overall mean equivalent income in the SCF, shown in the right-hand column of Table 3, is 143.5 percent of the median equivalent income in the CPS. This amount is about 11 percent higher than the average equivalent income reported in the CPS. The average income differences between the two surveys are larger for people in near-aged and aged households than they are for people who are members of nonaged households. Compared with the average equivalent incomes reported in the CPS, the average incomes in the SCF are 6.4 percent higher for the nonaged, 30.3 percent higher for the near-aged, and 16.1 percent higher for the aged. Nonetheless, respondents with a lower rank in the income distribution have lower absolute incomes in the SCF than do

\footnotetext{
${ }^{6}$ Note that this estimate reflects households' pretax money incomes. If instead we calculated post-tax money incomes, including refundable tax credits under federal and state income tax systems, the relative incomes of Americans at the bottom of the income distribution would represent a larger percentage of the median income. The CPS files include Census Bureau imputations of payroll taxes and personal income taxes. We do not perform aftertax calculations in this paper, however, because the SCF files do not include such imputations. Furthermore, much of our analysis involves making adjustments to reported gross income amounts to offset the effects of income misreporting. It is beyond the scope of this paper to develop tax imputation formulas to recalculate income and payroll taxes after reported income amounts have been changed.
} 
respondents with equivalent positions in the CPS, and this generalization is valid whether a person is a member of an aged, near-aged, or nonaged household. Compared with the CPS, higher incomes are found in the SCF for people in the top fifth of the income distribution, and the difference is particularly large in the case high-income people who are members of near-aged and aged households.

The two surveys show some similar income patterns. For example, at the bottom of the income distribution in both surveys, people who are members of aged households receive somewhat higher incomes than people who have a comparable position in the nonaged and nearaged income distributions. At higher ranks of the income distribution, people in aged households have lower incomes than their counterparts in nonaged and near-aged households.

The results in Table 2 suggest that if the SCF is more successful than the CPS in matching the NIPA money income totals it is because it captures a larger percentage of highincome households' incomes. This success translates into higher relative incomes among the aged and near-aged, but primarily for households which have a high rank in the income distribution. We are skeptical, however, that the SCF income reports give us an accurate indication of incomes in the middle and at the bottom of the distribution. The reported income amounts seem suspiciously low when compared with amounts reported to CPS interviewers at comparable positions in the income distribution.

\section{Adjusting CPS Money Income to Reflect Underreporting}

Less income is reported in household survey files than in the NIPAs for a variety of reasons. Some income recorded in the NIPAs is received by people who are institutionalized or who are otherwise excluded from the CPS and SCF sampling frames. Other income is received by people who are deceased by the date of the annual CPS income supplement in February, March, or April of the following calendar year. We followed Roemer (2000) in adjusting our money income benchmarks to reflect these factors, but the income reported in the CPS still falls short.

Assuming the NIPA income benchmarks are correct, the remaining shortfall must be due to underreporting of actual income amounts by people who report receiving a particular kind of 
income or the failure to report an income item by some people who receive it. ${ }^{7}$ For several kinds of income it is possible to compare household survey responses to income reports in administrative data sources, including W-2 forms, tax returns, and social security payment records. This kind of comparison is not always feasible, however. The large shortfall of selfemployment income reported in the CPS is mirrored by an equally large shortfall in selfemployment income reported in income tax returns. Many people who collect pensions do not have to report them on tax returns because their incomes are too low to require them to file a return. Thus, the underreporting of income may be just as serious a problem in administrative data records as it is in household surveys.

It is clear in Table 1 that some forms of income are in the aggregate more accurately reported in one household survey file than another. A higher proportion of benchmark earned income is reported in the SCF than in the CPS, for example. It is conceivable that the distribution of wage and salary income is more reliably reflected in the SCF than in the CPS. In 2000 an identical fraction of households in both surveys -77.3 percent - reported receiving wage income, and the total wages reported in the SCF were almost identical to the benchmark wage and salary total derived from the NIPAs. The principal difference between wage reports in the two surveys is that top wage earners reported receiving substantially higher wages in the SCF than in the CPS whereas low wage earners in the SCF reported receiving lower wages than their counterparts in the CPS.

To determine the effect of the differing wage distributions on the relative incomes of households headed by young and old adults, we substituted the wage distribution in the SCF for that in the CPS. The substitution is straightforward in 2000 because an identical percentage of households in both surveys contained wage earners in that year. Households in both surveys were ranked from lowest to highest in order of their wage and salary earnings. ${ }^{8}$ A household with a given rank in the CPS sample was then assigned the mean wage earnings of the SCF

${ }^{7}$ The Census Bureau uses hot-decking procedures to impute the value of an income item when a respondent indicates the income item was received but fails to report the income amount. The CPS income estimates shown in Table 1 and Figures 1 and 2 include these Census imputations.

${ }^{8}$ Note that there is a small difference in the definition of wage and salary income in the two surveys. In the CPS, wage and salary income is supposed to include Subchapter S corporation income, whereas income from this source is included in self-employment income in the SCF. According to NIPA estimates, Subchapter S corporate income was about 4 percent of total wage and salary income in 2000. We made no adjustment to reflect this definitional difference. We are skeptical that a large percentage of Subchapter S corporation income is actually included in wage and salary income in the CPS. 
households who had the identical wage rank. ${ }^{9}$ The "underreporting adjusted" wage distribution for CPS households is identical to the presumably more accurate wage distribution observed in the SCF. Wage and salary income for each CPS household was then multiplied by a constant ratio so that when summed, the adjusted wage amounts for CPS households totaled the NIPA benchmark.

Adjusting the self-employment income reports on the CPS to reduce the effects of income underreporting is more difficult. In 2000 CPS respondents reported only about half of the total self-employment income recorded in the NIPAs. In contrast, respondents to the SCF reported self-employment earnings that were about 98 percent of the NIPA benchmark. In spite of the evident superiority of self-employment income reports on the SCF, a somewhat higher percentage of CPS respondents indicated receiving self-employment income. One possibility is that a larger proportion of persons who earned small amounts of self-employment income reported their earnings on the CPS, but self-employed workers in the CPS who had high earnings reported less than the full amount of their earnings. Thus, compared with the SCF the CPS obtained more accurate reports from respondents with low self-employment income but less accurate reports among respondents with high self-employment income. To adjust the CPS selfemployment income reports, we therefore left unchanged the reported self-employment earnings reports of households with self-employment income below $\$ 30,000$ but adjusted the earnings amounts of households with higher annual earnings so they duplicated the earnings pattern observed in the SCF survey. (An identical percentage of households in both surveys had selfemployment income in 2000 that exceeded \$30,000.) Self-employment income for each household in the CPS was then multiplied by a constant ratio so that total self-employment income equaled the benchmark self-employment income derived from the NIPAs.

In order to adjust the CPS capital income reports so total income on the CPS approximates the amount in the NIPA benchmark, we considered a variety of adjustment methods. The SCF capital income reports do not seem to be a good alternative source of data. The reporting differences between the SCF and CPS make us skeptical that the capital income reported in the $2001 \mathrm{SCF}$ is more accurate than the capital income reported in the $2001 \mathrm{CPS}$. In

\footnotetext{
${ }^{9}$ For wage earning households in the two surveys, we implemented this idea as follows. After ranking households in each survey in order of their wage earnings, we divided households into 500 equal-size cells and calculated the mean wage earnings within each cell, say, $\hat{\mathrm{E}}_{\mathrm{CPS}, \mathrm{i}}$ for the CPS households and $\hat{\mathrm{E}}_{\mathrm{SCF}, \mathrm{i}}$ for the SCF
} 
2000 the total amount of capital income reported on the CPS is closer to the NIPA benchmark than is the capital income reported on the SCF. In comparison with SCF respondents, a larger percentage of CPS respondents reported receiving interest, dividend, and rent and royalty income. Rather than adjust the CPS capital income reports to reflect the reports in the SCF, we modestly increased the reported capital income amounts of each household who reported receiving such income. CPS respondents reported receiving 7.8 percent less capital income than the benchmark NIPA amount in 2000, so it is only necessary to increase reported capital income amounts by 8.5 percent in the aggregate. ${ }^{10}$

The results in Table 1 suggest that the CPS provides more accurate reports on government transfer income than the SCF. For some government transfers it may be possible to obtain more reliable income reports from the Survey of Income and Program Participation, or SIPP (Roemer 2000). However, we do not perform that exercise here. It is unclear which household survey obtains more reliable reports of pension income. The reported totals of pension income are well below the target amount derived from the Statistics of Income. Moreover, reported government employee pensions are far lower in the CPS than they are in the NIPAs, and the discrepancy has grown larger over time. Since we could identify no better source of information about regular pension payments, we left the CPS pension reports unchanged.

Our adjustments to 2000 CPS wage, self-employment, and capital income reports add about $11 \frac{1}{2}$ percent to the total money income reported by CPS respondents and eliminate twothirds of the shortfall in reported income below the NIPA benchmark. Table 3 shows how equivalent money income is affected by our adjustments for underreporting at selected points in the income distribution for aged, near-aged, and nonaged households. The top row shows income changes for the entire population. The underreporting-adjusted estimates of money income are lower than the originally reported income amounts for CPS respondents in the bottom three-quarters of the income distribution. This is due almost entirely to the fact that households with below-average wages report lower wage incomes in the SCF than in the CPS. At the $95^{\text {th }}$

households. To determine the effect of substituting the SCF wage distribution for the CPS wage distribution, we simply substituted $\hat{\mathrm{E}}_{\mathrm{SCF}, \mathrm{i}}$ for $\hat{\mathrm{E}}_{\mathrm{CPS}, \mathrm{i}}$ while leaving other income items unchanged in the CPS file.

${ }^{10}$ We separately adjusted each capital income item. Respondents who reported receiving interest income had interest adjusted upward by 4.4 percent of the originally reported amount; reported dividends were increased 2 percent; and reported rent, royalty, and trust income was increased 38.7 percent. After adjustment, the new CPS capital income totals are equal to the benchmark totals derived from the NIPA. 
percentile of the income distribution, the estimated equivalent income rises by almost 11 percent. The average change for the entire population is 12.1 percent, indicating that most of the additional income is received by members of households in the top 5 percent of the income distribution.

The lower rows in Table 3 show changes in the income distribution in nonaged, nearaged, and aged households. The adjustments for underreporting have small effects on members of households headed by an aged adult. The effects are much bigger in the case of households headed by a working-age person, especially at the top and near the bottom of the income distribution. This pattern reflects the types of underreporting adjustments we made to the data. By far the largest adjustments were in earned income, that is, income from wages and selfemployment. Because aged households receive relatively little of their income in the form of earnings, the adjustments will have little impact on their total incomes. The adjustments of capital income have a bigger effect on the aged, but mainly on aged households that derive a large percentage of their incomes from rent, royalty, and trust income. Not surprisingly, these households are near the top of the income distribution.

Unfortunately, our adjustment procedures do not change reported amounts of government transfers or pension income, income sources where there are serious underreporting problems. It is likely that a correction for transfer underreporting would improve the relative position of lower income households headed by both aged and nonaged adults. A correction for underreported pension income would clearly improve the relative position of the aged and near-aged households. It is less clear whether the improvement would be relatively bigger near the top or bottom of the income distribution. The results in Table 3 remind us, however, that the single most important kind of underreporting is for earned income. Corrections of this underreporting will increase the average incomes of the nonaged much more than the aged. 


\section{Counting Income Flows from Housing}

Money income is a meaningful but incomplete measure of the resource flow available to households in order to support consumption. About two-thirds of U.S. households live in a house or apartment that is owned by an occupant. Residents of these households obtain a flow of services that is not counted in money income but that does free up part of their money income to be spent on other items.

The Census Bureau recognizes the value of the implicit income flow from homeownership. To construct one of its experimental income measures, the Bureau imputes an estimate of implicit rental income from owner-occupied homes based on the assumed financial return that homeowners could earn on the net equity they hold in their homes. A household's net home equity is simply the difference between the market value of its home and the balance on the home mortgage. The Bureau assumes that homeowners earn a return on net home equity equal to the municipal bond rate. From this estimate of financial return the Bureau subtracts one of the main costs of ownership, the homeowner's property tax. The surplus of return on net home equity over the property tax liability is counted as income in the Bureau's experimental income measure number 15 (Cleveland 2005). All of these imputations of home value, mortgage balances, and property tax liabilities are based on responses from the American Housing Survey.

No imputation is needed in the SCF file to derive an estimate of homeowners' net equity. Since the SCF is a wealth survey, respondents are asked to report the value of their homes and the remaining balances on their home mortgages and loans. SCF interviewers do not ask respondents to estimate their property tax payments, however, so an imputation would be needed to calculate the implicit income from home ownership in the same way that it is done on the CPS. We can nonetheless compare the Census Bureau's imputations of the return on net home equity, prior to deducting property taxes, with estimates based on home value and mortgage reports in the SCF applying the same municipal bond rate. Measured as a percentage of households' equivalent money incomes, the estimated return on net home equity represents a somewhat larger income item in the SCF than in the CPS. In the years between 1988 and 2000 where both CPS and SCF estimates are available, the return on net home equity represents 6.7 percent of equivalent money income on the CPS and 7.2 percent of equivalent money income on the SCF. For the median income recipient in both surveys, the return on net home equity 
represents 7.4 percent and 8.5 percent of money income, respectively. ${ }^{11}$ In both surveys, home equity returns, if included in income, would yield a larger increase in the incomes of households in the bottom half of the income distribution, and the increase would represent a substantially larger gain for aged and near-aged households than for nonaged households.

The comparisons just described do not take account of any of the costs of homeownership except the implicit cost of financing a mortgage. As noted above, the CPS files also contain an estimate of homeowners' property tax bills. These can be subtracted from homeowners' returns on net home equity to obtain the Census Bureau's estimate of housing income flows. Figure 4 shows the effect of adding these income flows to money income reports in the CPS surveys for selected years between 1988 and 2000. (The public-use version of the CPS file covering 2003 incomes does not include the Bureau's imputations of home equity returns.) In the figure we average the results for five years, 1988, 1991, 1994, 1997, and 2000. However, the results are broadly similar in all of the years. The figure shows separately our results for households with nonaged, near-aged, and aged heads. The bars on the left show estimated changes in equivalent income at selected points in the income distribution.

In general, the inclusion of income flows from homeownership produces bigger proportional income gains in the bottom half of the income distribution and among aged and near-aged households. The median person in a nonaged household would see income rise 3.3 percent if housing income flows were added to money income; the median person in a near-aged household would see counted income rise 7.5 percent; and the median person in an aged household would see a gain of 16.3 percent. The proportional gains in income are larger further down the distribution, and the gains shrink as incomes rise above the median. On average the equivalent incomes of members of aged households would be 11.8 percent higher if housing income flows were added to money income. The average income gain for members of nonaged households is only 3.3 percent. Clearly, counting the income flows from homeownership significantly improves the relative income positions of people in aged households.

11 Since we use the same interest rate to calculate returns on net home equity in the SCF files that the Census Bureau uses in the CPS files, the higher estimates of returns in the SCF files must be due to higher reported amounts of net home equity in the SCF files than the Census Bureau imputes on the CPS files. 


\section{Counting the Annuity Value of Pension Wealth}

As we have seen, pension income is substantially underreported in both the CPS and SCF surveys. Even if the payments from defined-benefit pension plans were accurately reported in household surveys, however, there would remain a problem with the way defined-contribution (DC) pension accounts and IRAs are treated in the money income statistics. The treatment of DC pension and IRA withdrawals in the definition of money income leads to a substantial understatement of DC pension plans' contributions to the resources available for financing consumption in old age. If we compare two workers, one enrolled in a DB plan and another enrolled in a DC or IRA plan, the treatment of withdrawals from their pension accounts differs greatly under the current definition of money income. Regular pension payments from a DB plan are included in the definition of money income. However, withdrawals from a DC or IRA plan are only included if they represent a regular income flow. For most workers, withdrawals from a DC plan or from an IRA are too erratic to be classified as a regular income flow. Consequently, a large fraction of withdrawals is intentionally excluded from money income. (We do not know how many workers disregard interviewers' instructions and include irregular DC and IRA pension withdrawals in their reports of pension income. We suspect the number is small.) The problem with this treatment is that retired workers can finance as much consumption using \$100 in DC or IRA retirement plan withdrawals as they can with \$100 in DB pension payments.

One approach to the problem is to include taxable DC and IRA pension withdrawals in money income, thus treating these withdrawals as equivalent to DB pension payments. From an accounting standpoint, one advantage of this approach is that it closely aligns the definition of money income with the taxable income flows from pension plans, included IRAs. Workers who make taxable withdrawals from an IRA or DC pension account would be asked to report these withdrawals as money income in the income survey. They are of course also required to report them on federal income tax returns. The total reported withdrawals on the survey can then be compared with estimates derived from IRS tax files. In order to implement this approach, it is necessary to change the questions posed in the CPS interview. A disadvantage of the approach is that it may produce a spurious increase in measured income inequality. Many retirees make large withdrawals in some years and negligible withdrawals in others. Funds in their retirement accounts are available to pay for consumption, even in years when no withdrawals are made. 
Under the proposed approach, a worker who makes no withdrawal may be erroneously classified as "poor," even though funds in the retirement account are earning a return that represents a large percentage of the total income received by the worker's family.

An alternative approach to measuring DC incomes is to calculate the annuity payment a worker can purchase with the funds available in his or her pension account. Under this procedure, both regular and irregular withdrawals from a DC or IRA account would be excluded from the new measure of income. Instead, the new measure would include the predicted annuity payment. The prediction would vary with workers' IRA and DC account balances, with their ages and marital status, and with prevailing interest rates. In combination, these sources of variability are important, but they are probably less important than the variability that arises because of irregular pension withdrawals. It is straightforward to implement this approach to measuring DC and IRA pension flows using information from a survey, such as the SCF, that asks workers about their IRA and DC account balances as well as their incomes. It is harder to implement the procedure using a household survey that lacks any measure of pension wealth, as is the case with the CPS.

We have estimated annuity flows from DC pension wealth holdings reported in the SCF. In addition, we have used a statistical matching procedure similar to hot decking in order to impute DC pension wealth reported on the SCF file to households in the CPS sample. Hot decking is ordinarily used to impute missing data when there is survey non-response. This type of problem arises when a respondent fails to give a valid answer to a survey question. In a standard hot decking imputation, respondents in the sample are stratified into cells defined by several categorical variables. Within each cell, a donor (that is, an observation in the survey file who has a valid response) is randomly selected to represent each identified mis-reporter in the file. Once a donor and mis-reporter are matched, the valid responses of the donor are copied over to the mis-reporter (or non-respondent). In our case, donors are randomly selected from appropriately defined cells in the SCF file to supply wealth information for households in the CPS file. Our matching procedure classifies households in both the SCF and CPS into cells defined by four key variables: nine age groups (household head under 25, 25-34, 35-44, 45-49, $50-54,55-59,60-64,65-69$, and 70 and over); three capital income categories (low or zero income, moderate income, and very high income); three labor income categories (low or zero income, intermediate income, and high income); and three social security income categories (low 
or zero income, intermediate income, and high income). ${ }^{12}$ Our DC wealth imputations on the CPS file produce an estimate of total DC pension wealth that is within 0.1 percent of the aggregate DC pension wealth reported in the SCF file, an amount that is slightly more than $\$ 5.7$ trillion.

When an analysis file contains an estimate of a household's DC pension wealth, it is straightforward to calculate the annuity income flow that would be received by the household if the wealth holdings were converted into a life annuity. This calculation requires information about the wealth holder's future life expectancy, his or her plans for buying a single-life or jointsurvivor annuity, and the interest rate that the annuity seller will use in calculating the price of the annuity. In our estimates we assume that the asset holder purchases an annuity at the time of the interview and has a future life expectancy that can be predicted based on the annuity buyer's sex and the 2003 period life tables published by the Social Security Actuary. A single head of household is assumed to purchase a single-life annuity, and a married head of household is assumed to buy a joint life annuity in which the surviving spouse receives an annuity payment equal to 70 percent of the annuity received when both spouses are alive. Our calculations assume that the annuity price is determined by the rate of return on high-quality, intermediateterm bonds. Under one assumption, one-half of the bond portfolio consists of 10-year U.S. Treasury bonds and one-half consists of AAA-rated corporate bonds. Under an alternative, more conservative assumption, the portfolio consists only of intermediate-term indexed Treasury bonds. The results presented below are based on the more conservative interest rate assumption. (Details about our calculations are provided in Appendix B.)

Having calculated the annuity payment a family could receive if its DC pension savings were converted into an annuity, we then added this income flow to the money income reported by the household on the SCF or CPS file. The annuity payments can be added to the reported incomes of all households who have DC pension wealth or to only households where either the household head or the spouse of the head appears to be retired. We added annuities to money income using both procedures, but the results displayed in Figure 5 rest on the assumption that only retired workers draw annuity payments from their DC wealth holdings. We classify as "retired" all households in which the head or spouse of head is age 50 or older if their estimated

12 The labor income categories were only used to classify households with a head younger than 65; the social security income categories were only used to classify households with a head 65 or older. Additional details about the hot decking procedure are provided in Appendix B. 
annuity income is more than one-half the amount of their reported earned income (wages and salaries and net self-employment income). Thus, a household headed by an older person with no labor income but with DC pension holdings would have DC annuity income counted as part of income. Households headed by younger people or headed by an older person who has labor income that substantially exceeds his or her potential annuity would not have the estimated annuity included in income.

Figure 5 shows the effect of adding potential DC annuities to retirees' money incomes. Results in the top panel show our results when using pension wealth and income reports in the 2001 SCF; results in the bottom panel show our results when using income reports from the 2001 CPS file after DC pension wealth imputations have been made using wealth reports in the SCF. The findings from both files show a broadly similar pattern. The inclusion of estimated DC annuity payments in income produces a bigger percentage change in income at the top of the income distribution than at the bottom, and it produces proportionally larger increases in the estimated incomes of households headed by aged heads compared with households headed by the nonaged. In the SCF, the estimated incomes of the median person in a household headed by someone who is 55 or over increases by about 5 percent. For the average person in a household headed by someone between 55 and 64, estimated income increases by 3.5 percent. For the average person in a household headed by someone 65 or older, income rises by 10.3 percent. Not surprisingly, there is virtually no effect of including predicted DC annuities on the incomes of people who are members of families headed by someone younger than $55 .^{13}$

Although the overall pattern of effects is similar in both the SCF and CPS files, there are a couple of differences worth mentioning. The proportional effect of including DC pensions on the incomes of people in households headed by an aged or near-aged adult is somewhat larger in the CPS file than it is in the SCF file. The main reason for this, both on average and for households near the top of the income distribution, is that the CPS file shows lower money incomes than the SCF file. Even though the predicted average annuity benefit is the same in both files, the higher level of reported money income in the SCF file means that this annuity

13 The results are similar when we add predicted DC annuities to the money incomes of all households reporting DC pension wealth, regardless of whether the head of household or the spouse of the head is retired. The most important effect of using this alternative procedure is that the relative incomes of people in households headed by a near-aged person are increased in comparison to the incomes of people in households headed by a person under age 55 or older than age 65 . The reason is that many people between ages 55 and 64 have accumulated substantial DC pension wealth, but they have not yet retired under our definition. 
benefit is a smaller percent of income in the SCF file. In the middle and at the bottom of the income scale, however, the CPS shows higher money incomes than the SCF file. In this part of the income distribution, the proportional effect of including DC annuities in income is bigger in the CPS than the SCF because our hot-decking imputation procedure predicts DC pension wealth that is somewhat higher than the pension wealth observed in the SCF. Even with this imputation problem, it should be obvious that the inclusion of DC annuities will not add substantially to the incomes of people near the bottom of the income distribution. The primary effect of including DC annuities is to increase noticeably the measured incomes of aged and near-aged households, especially in the top quarter of the income distribution.

\section{Counting the Annuity Value of Financial Wealth and the Income Flow from Owner- Occupied Housing}

The income adjustments made in the previous section offer a way to treat pension accumulations and payouts in a similar way whether fund accumulation occurs in DC or DB pension plans. Employer contributions to such plans are not counted as household income in the year when contributions are made, nor are the capital returns on pension holdings included in household income. Instead, household income is defined to include withdrawals or predicted withdrawals from the plans in years after the worker has retired. Workers may of course accumulate savings for retirement outside of pension plans, for example, in bank accounts or mutual fund accounts. In this case, income measurement involves some of the same analytical issues that arise in the case of DC pension saving. The accumulation of financial wealth outside of pension accounts allows retired workers to consume more than their measured income, but none of this wealth accumulation is counted when comparing the income positions of the young and the old.

It is possible to treat non-pension wealth accumulation in a way that is similar to our treatment of DC pension accumulation in the previous section. Funds accumulated in nonpension accounts can be added to those accumulated in DC pension accounts, and the total can be converted to an annual annuity payment. The predicted annuity is then added to the household's other income in order to determine the total income flow available to the household to finance consumption. In this case, however, it is essential to make an adjustment to the household's other income sources in order to avoid double counting capital income. In particular, reported interest and dividend income must be excluded from a household's income if 
we include the annuitized income flow that can be financed out of the household's financial wealth. The predicted annuity income flow already includes an interest income flow.

We have calculated annuity income flows out of financial wealth accumulation in much the same way as we calculated the potential annuity income flow out of DC pension accumulations. In the case of the SCF, the data file already includes a complete record of each household's financial wealth holdings, including DC pension accumulations. A household's net financial wealth holdings consists of bank deposits, stocks, bonds, mutual fund and other pooled investment holdings, DC retirement accounts (including IRAs), the cash value of life insurance policies, and other miscellaneous financial accounts, minus household debt (except the mortgage on the household's principal residence). In the case of the CPS, each household's total financial wealth holdings must be imputed based on wealth reports in the SCF file. We use the same statistical imputation procedures that were described in Section 5 above. Annual annuity payments are calculated by converting these wealth holdings into a level annual annuity payment that is expected to last for the lifetime of the household head or, if the household head is married, for the lifetime of the longer-lived spouse. We use the same interest rate assumptions as those discussed in Section 5.

The impact of adding annuity flows from all financial wealth holdings is shown in Figure 6. The top panel shows estimates based on income and wealth reports in the SCF; the bottom panel shows results based on income reports in the CPS plus wealth imputations derived from the SCF. The estimates in both panels are based on the assumption that financial wealth is annuitized for each household in the sample, regardless of the age or retirement status of the household head and spouse of the household head. We add the calculated annuity to money income reported in the CPS or SCF file, and we subtract from the household's money income reported capital income earned on financial assets.

The results from the CPS and SCF are broadly similar. The addition of annuity income flows from wealth substantially raises the relative incomes of near-aged and aged households compared with nonaged households, especially in the top half of the income distribution. The effects of these additions are proportionally somewhat larger in the CPS file, primarily because reported money incomes in the top quarter of the income distribution are smaller in that file. For nonaged households at the $50^{\text {th }}$ percentile of the income distribution, the inclusion of annuity incomes and the exclusion of reported capital income sources increases measured incomes by 
about 4 or 5 percent. For the median near-aged household, the inclusion of predicted annuity incomes increases measured incomes by 16 percent in the SCF and by 15 percent in the CPS. For the median aged household, the inclusion of predicted annuity incomes increases measured incomes by 26 percent in the SCF and 35 percent in the CPS. The proportional effect of including predicted annuities is substantially larger further up the income distribution. At the $90^{\text {th }}$ percentile, for example, incomes of near-aged households are increased 26 percent in the SCF and 34 percent in the CPS. At the same point in the income distribution, incomes of aged households rise about 63 percent in both the SCF and the CPS. At the bottom of the income distribution, the effects of including annuitized wealth are far smaller, mainly because households with low money incomes typically have very little wealth.

The tabulations displayed in Figure 6 show that the addition of annuitized income flows has a comparatively small impact on the measured income of households headed by a person who is under 55. This is not surprising. Households headed by younger people have accumulated less financial wealth than households headed by someone who is 55 or older. In addition, when the wealth accumulation of a younger person is converted into a lifetime annuity, the annual annuity payment will be relatively small because remaining life expectancy is longer for the young than it is for the old.

Adding returns on net home equity. We can combine the results in this section with those derived in Section 3 by adding both annuitized wealth and returns on net home equity to the adjusted money incomes reported on the SCF and CPS and excluding directly-reported capital income. According to the $2001 \mathrm{SCF}$, more than two-thirds of the net worth of U.S. households consists of financial assets and net equity in a principal residence. Remaining wealth consists mainly of holdings of residential and nonresidential property other from the household's primary residence, equity in a business, and personal vehicles minus household debt excluding debt on a primary residence (Bucks, Kennickell, and Moore 2006). By replacing respondents' reported capital income with estimates of income flows from financial assets and owner-occupied homes, we can obtain a rough approximation of the resources that are available to sustain household consumption.

When both forms of capital income are included in money incomes, the relative income position of aged and near-aged households improves considerably compared with that of nonaged households. Although the gains are noticeable both in the top and bottom ranks of the 
income distribution, they are larger in the top half of the distribution. For a nonaged household at the $50^{\text {th }}$ percentile of the income distribution, the inclusion of annuity incomes and the exclusion of reported capital income sources increases measured incomes by about 9 percent. For the median near-aged household, the inclusion of predicted annuity incomes increases measured incomes by about one-quarter in both the SCF and CPS. For the median aged household, the inclusion of predicted annuity incomes increases measured incomes by 50 percent in the SCF and by 55 percent in the CPS. The proportional effect of including predicted annuities is substantially larger further up the income distribution. At the $90^{\text {th }}$ percentile, incomes of near-aged households increase by 35 percent in the SCF and by 40 percent in the CPS. Incomes of aged households rise about 72 percent in both the SCF and the CPS. At the bottom of the income distribution, the effects of including annuitized wealth are smaller though hardly trivial. Under an income definition that includes annuity flows from financial wealth and the returns on net home equity, the estimated income of a nonaged household at the $10^{\text {th }}$ percentile of the income distribution rises by 6 or 7 percent. The estimated income of an aged household at that position in the income distribution increases 29 percent in the SCF and 34 percent in CPS.

\section{Conclusion}

Capital income flows to both aged and nonaged households are underreported in most household surveys, including the principal surveys used to estimate the size distribution of U.S. income. Some of the understatement occurs because capital income that should be reported by survey respondents is incompletely reported or not reported at all by some respondents. Most of the understatement is due to conceptual limitations of the Census Bureau's definition of "money income." The definition excludes income flows from some kinds of household wealth, including owner-occupied housing and assets held in DC pension accounts that are particularly important for households headed by an aged person.

In this paper we have tried to assess the importance of income underreporting in the CPS and SCF survey files. We are particularly interested in the effects of underreporting on assessments of the relative income position of the aged. Our tabulations suggest that underreporting is a major issue in both the CPS and the SCF. Compared with the CPS, the SCF uncovers a larger percentage of the total money income that is reported in the national accounts. This is mainly because high-income respondents in the SCF report much higher incomes than 
comparable respondents in the CPS. However, the SCF appears to miss a substantially larger fraction of the capital, labor, and transfer payment income received by households in the lower ranks of the income distribution. Thus, both surveys have major shortcomings as a source of accurate information on household incomes.

When we adjust reported money incomes in the surveys to reflect sources of capital income that are excluded from money income, we find a substantial improvement in the relative position of aged and near-aged households compared with the nonaged. Tables 4 and 5 summarize our results using alternative definitions of 2000 income. Table 4 shows results based on CPS income reports supplemented with imputations of DC pension wealth and financial wealth derived from the 2001 SCF file. Table 5 shows results based on income and wealth reports from the $2001 \mathrm{SCF}$ file. The estimates in each table show the distribution of income under five alternative measures of household income: (1) Census money income; (2) Census money income plus the return on net home equity; (3) Census money income plus the predicted annuity on retirees' DC pension holdings; (4) Adjusted Census money income plus the predicted annuity on households' financial wealth holdings (including DC pension holdings); and (5) The sum of income under definition \#4 plus the return on net home equity. ("Adjusted Census money income" excludes the income reported by households that is derived from financial assets, such as interest and dividend income.) For each definition of income, the tables measure income as a percent of the median household-size-adjusted income estimated under that definition.

In both the CPS and SCF files, the relative position of aged households is worse under the money income definition than it is under more comprehensive definitions, and the relative income position of aged households is best under the broadest income definition. Under the money income definition, both the median and average income of aged households are considerably lower than the corresponding income amounts for nonaged households. For example, in the CPS the median money income in aged households is 28 percent lower than the overall median income while the median money income in nonaged households is 4 percent higher than the median money income in the entire population. Under the broadest definition of income, which includes an estimate of the annuity on financial assets as well as returns on net home equity, the median incomes of people in aged and nonaged households are essentially identical. Under the money income definition, the average income of members of aged 
households is substantially below the average income in nonaged households. Under the broadest income definition, it is substantially higher than the average income in nonaged households.

The distributional effects of using a broader income definition may be even clearer in Figures 8 and 9. Both charts show the distribution of the logarithm of household-size-adjusted income separately for nonaged, near-aged, and aged households. The top panel in both figures shows the income distribution when income is measured using the Census Bureau's money income definition. The bottom panel shows the income distribution under our broadest measure of income. In both survey files and under both income definitions, the household-size-adjusted incomes of people in near-aged households are nearly always higher than incomes in nonaged and aged households at the equivalent position in the income distribution. However, the relative position of aged households depends crucially on whether money income or a broader income definition is used to estimate household incomes. Except in the lowest ranks of the income distribution, when income is measured using the Census Bureau's money income definition, aged households look considerably worse off than nonaged households in the same part of the income distribution. However, under the broadest measure of household income, aged and nonaged households appear to have similar incomes in the middle of the income distribution, and aged households have higher incomes than the nonaged both in the top quarter and the bottom quarter of the income distribution.

Two major goals of U.S. tax and income security policy are to increase homeownership and encourage savings accumulation in private retirement accounts. In comparison with other industrialized countries, the United States has achieved high homeownership rates and its workers have accumulated large reserves in occupational pension plans and dedicated retirement accounts. Under the standard definition of money income used by the Census Bureau, very little of the income flow that is generated by these forms of wealth is included in household income. Using a broader income definition that includes these income flows, the relative position of the nation's elderly is substantially improved. Under the broadest definition of income we consider here, the economic status of America's aged households appears to be approximately the same if not better than that of the nonaged households. 


\section{References}

Bucks, Brian K., Arthur B. Kennickell, and Kevin B. Moore. 2006. "Recent Changes in U.S. Family Finances: Evidence from the 2001 and 2004 Survey of Consumer Finances" Federal Reserve Bulletin 92 (February):A1-A38.

Cleveland, Robert W. 2005. Alternative Income Estimates in the United States: 2003. Series P60228. Washington, D.C.: U.S. Census Bureau.

Moore, James, and Leslie Muller. 2002. “An Analysis of Lump-sum Pension Distribution Recipients," Monthly Labor Review (May): 29-37.

Roemer, Marc I. 2000. "Assessing the Quality of the March Current Population Survey and the Survey of Income and Program Participation Income Estimates, 1990-1996.” (June 16, 2000) Suitland, MD: Income Surveys Branch, Housing and Household Economic Statistics Division, U.S. Census Bureau.

Ruser, John, Adrienne Pilot, and Charles Nelson. 2004. "Alternative Measures of Household Income: BEA Personal Income, CPS Money Income, and Beyond.” Paper prepared for the Federal Economic Statistics Advisory Committee (December 14, 2004). Washington, D.C.: U.S. Bureau of Economic Analysis.

Sabelhaus, John, and David Weiner. 1999. "Disposition of Lump-Sum Pension Distributions: Evidence from Tax Returns," National Tax Journal 52(3) (September): 593-613.

Schieber, Sylvester J. 1995. “Why Do Pension Benefits Seem So Small?” Benefits Quarterly 11(4): 57-70.

Smeeding, Timothy, and Jeffrey Thompson. 2007. "Income from Wealth and Income from Labor: Stocks, Flows and More Complete Measures of Well Being," mimeo, Center for Policy Research, Syracuse University.

Toder, Eric, and others. 1999. Modeling Income in the Near Future - Projections of Retirement Income Through 2020 for the 1931-60 Cohorts. (Washington: Urban Institute and U.S. Social Security Administration). [http://www.urban.org/socsecurity/MINT_full.pdf]

U.S. Bureau of the Census. 1993. Money Income of Households, Families, and Persons in the United States: 1992. Current Population Reports, Series P60-184. Washington, D.C.: U.S. GPO.

Wolff, Edward N., and Ajit Zacharias. 2006. "Household Wealth and the Measurement of Economic Well-Being in the United States." Levy Economics Institute Working Paper No. 447. Annandale-on-Hudson, NY: Levy Economics Institute, Bard College.

Woods, James R. 1996. "Pension Benefits among the Aged: Conflicting Measures, Unequal Distributions." Social Security Bulletin 59(3) (Fall): 3-30. 
Table 1. Money Income Reported on Household Survey Files as a Percent of NIPA Benchmark, 1988 - 2003

Percent

\begin{tabular}{|c|c|c|c|c|c|c|}
\hline Category of income & 1988 & 1991 & 1994 & 1997 & 2000 & 2003 \\
\hline \multicolumn{7}{|c|}{ Income reported on Current Population Survey as \% of NIPA benchmark } \\
\hline Earnings $\underline{1} /$ & 89.6 & 88.3 & 86.0 & 90.3 & 88.5 & 91.2 \\
\hline Wages (including Subchapter S corporate income) & 93.3 & 91.9 & 91.4 & 94.8 & 93.4 & 96.4 \\
\hline Self-employment Income & 60.2 & 59.5 & 46.2 & 56.5 & 51.7 & 51.6 \\
\hline Capital Income & 68.7 & 62.3 & 72.8 & 108.0 & 92.2 & 78.3 \\
\hline Interest & 67.7 & 62.7 & 77.7 & 127.9 & 95.8 & 86.3 \\
\hline Dividends & 53.2 & 47.4 & 62.0 & 92.2 & 97.7 & 60.6 \\
\hline Rents, royalties, and trusts & 111.1 & 96.9 & 75.0 & 86.6 & 72.1 & 99.2 \\
\hline Transfers & 87.4 & 84.9 & 87.8 & 87.6 & 88.7 & 86.8 \\
\hline Workers compensation and unemployment insurance & 68.2 & 71.7 & 70.9 & 64.1 & 62.3 & 64.9 \\
\hline SSI and other cash public assistance & 86.8 & 91.7 & 88.2 & 87.5 & 86.2 & 86.4 \\
\hline OASDI & 90.5 & 85.7 & 90.6 & 90.7 & 92.6 & 90.9 \\
\hline Pensions $\underline{2} /$ & 96.6 & 93.1 & 87.6 & 79.7 & 70.8 & 74.9 \\
\hline Total Income & 88.6 & 86.5 & 86.2 & 91.3 & 88.5 & 90.0 \\
\hline \multicolumn{7}{|c|}{ Income reported on Survey of Consumer Finances as a \% of NIPA benchmark } \\
\hline Earnings $\underline{1} /$ & 99.7 & 101.8 & 98.3 & 98.3 & 100.2 & 97.2 \\
\hline Wages (excludes Subchapter S corporate income) & 101.5 & 100.0 & 102.1 & 100.9 & 104.6 & 106.1 \\
\hline Self-employment Income & 86.8 & 115.0 & 75.5 & 83.5 & 75.7 & 47.2 \\
\hline Capital Income & 116.7 & 95.9 & 122.8 & 123.1 & 131.9 & 184.7 \\
\hline Interest & 83.0 & 65.2 & 92.6 & 93.2 & 99.0 & 93.7 \\
\hline Dividends & 98.1 & 76.1 & 115.4 & 95.9 & 102.3 & 72.5 \\
\hline Rents, royalties, and trusts & 402.9 & 352.5 & 225.5 & 239.1 & 280.3 & 733.0 \\
\hline Transfers & 69.6 & 61.3 & 56.8 & 56.5 & 68.7 & 71.7 \\
\hline Workers compensation and unemployment insurance & 41.2 & 48.9 & 34.8 & 30.7 & 32.4 & 39.3 \\
\hline SSI and other cash public assistance & 55.4 & 47.2 & 41.5 & 26.5 & 20.8 & 28.4 \\
\hline OASDI & 77.9 & 67.6 & 64.8 & 67.5 & 85.1 & 88.4 \\
\hline Pensions $\underline{2}$ & 105.6 & 94.9 & 96.9 & 84.4 & 70.3 & 93.9 \\
\hline Total Income & 101.5 & 105.6 & 97.2 & 96.6 & 99.2 & 100.3 \\
\hline
\end{tabular}

$\underline{1}$ / For the CPS, the NIPA benchmark includes Subchapter S income in wages; for the SCF, the NIPA benchmark includes subchapter $\mathrm{S}$ income in self-employment income.

$\underline{2}$ / Federal employee pensions, military pensions, state and local employee pensions, and private pensions. The pension benchmark is derived from the IRS Statistics of Income file rather than the NIPA.

Sources: Bureau of Economic Analysis NIPA files; IRS Statistics of Income files; and authors' tabulations of public-use Current Population Survey and Survey of Consumer Finances files, selected years. 
Table 2. Equivalent Money Income Reported in the CPS and SCF Surveys, by Position in the Income Distribution, 2000

Median income in the CPS file $=100$

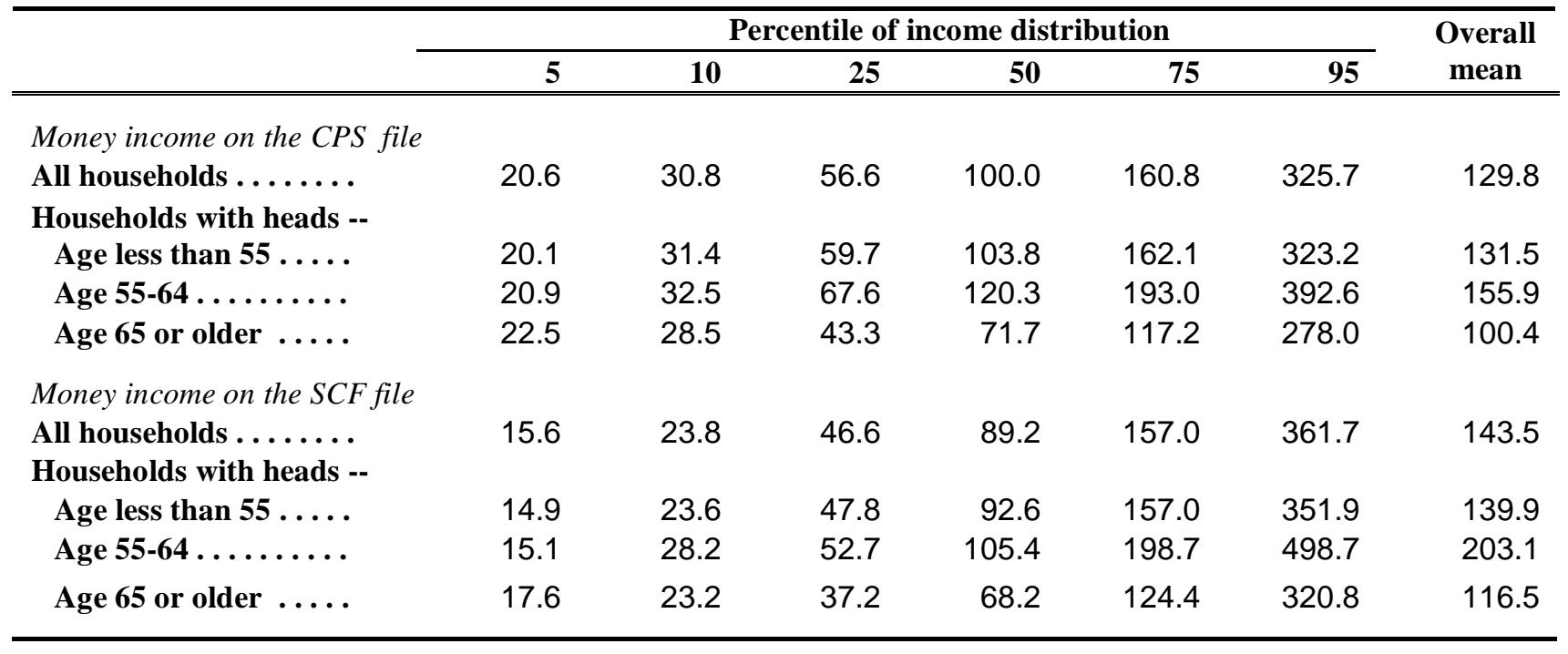

Note: Calculations are performed using "equivalent" or household-size-adjusted incomes for each household. Entries show equivalent income measured as a percent of the median size-adjusted income reported in the 2001 March CPS file.

Source: Authors' tabulations of 2001 March CPS file and 2001 SCF file.

Table 3. Change in Equivalent Money Income Resulting from Corrections for Underreporting of Money Income in the CPS File, 2000

Percent change

\begin{tabular}{|c|c|c|c|c|c|c|c|}
\hline & \multicolumn{6}{|c|}{ Percentile of income distribution } & \multirow{2}{*}{$\begin{array}{c}\text { Overall } \\
\text { mean }\end{array}$} \\
\hline & 5 & 10 & 25 & $\mathbf{5 0}$ & 75 & 95 & \\
\hline All households ........ & -4.1 & -3.6 & -3.9 & -3.5 & 0.4 & 10.9 & 12.1 \\
\hline \multicolumn{8}{|l|}{ Households with heads -- } \\
\hline Age less than $55 \ldots$. & -6.3 & -5.2 & -5.5 & -3.1 & 0.5 & 11.3 & 12.1 \\
\hline Age $55-64 \ldots \ldots \ldots$ & -2.9 & -2.0 & -3.8 & -3.0 & 1.7 & 13.9 & 16.6 \\
\hline Age 65 or older ..... & 0.2 & -0.7 & -0.5 & -0.4 & -0.4 & 4.8 & 6.9 \\
\hline
\end{tabular}

Note: Calculations are performed using "equivalent" or household-size-adjusted incomes for each household. Changes in equivalent income are calculated as a percent of equivalent incomes before adjustment for underreporting.

Source: Authors' tabulations of 2001 March CPS file (see text) . 
Table 4. Relative Income at Selected Points in the Income Distribution under Alternative Definitions of Income, by Age of Household Head: Current Population Survey, 2000

Median income $=100$

\begin{tabular}{|c|c|c|c|c|c|c|c|c|}
\hline & \multicolumn{7}{|c|}{ Percentile of income distribution } & \multirow{2}{*}{$\begin{array}{c}\text { Overall } \\
\text { Mean }\end{array}$} \\
\hline & 5 & 10 & 25 & 50 & 75 & 90 & 95 & \\
\hline & \multicolumn{8}{|c|}{ Money income } \\
\hline All households & 21 & 31 & 57 & 100 & 161 & 246 & 326 & 130 \\
\hline \multicolumn{9}{|c|}{ Households with heads -- } \\
\hline Age less than 55 & 20 & 31 & 60 & 104 & 162 & 243 & 323 & 132 \\
\hline Age 55-64 & 21 & 32 & 68 & 120 & 193 & 293 & 393 & 156 \\
\hline \multirow[t]{2}{*}{ Age 65 and older } & 22 & 28 & 43 & 72 & 117 & 200 & 278 & 100 \\
\hline & \multicolumn{8}{|c|}{ Money income + Return on net home equity } \\
\hline All households & 21 & 32 & 58 & 100 & 159 & 241 & 317 & 128 \\
\hline \multicolumn{9}{|c|}{ Households with heads -- } \\
\hline Age less than 55 & 20 & 31 & 58 & 102 & 159 & 237 & 311 & 128 \\
\hline Age 55-64 & 23 & 36 & 70 & 122 & 194 & 291 & 389 & 157 \\
\hline \multirow[t]{2}{*}{ Age 65 and older } & 25 & 33 & 50 & 80 & 125 & 207 & 280 & 106 \\
\hline & \multicolumn{8}{|c|}{ Money income + Retirees' estimated annuity on DC pension holdings } \\
\hline All households & 20 & 31 & 57 & 100 & 162 & 254 & 345 & 132 \\
\hline \multicolumn{9}{|c|}{ Households with heads -- } \\
\hline Age less than 55 & 20 & 31 & 58 & 102 & 160 & 244 & 323 & 130 \\
\hline Age 55-64 & 21 & 33 & 70 & 126 & 210 & 331 & 476 & 172 \\
\hline \multirow[t]{2}{*}{ Age 65 and older } & 22 & 29 & 45 & 77 & 133 & 235 & 327 & 114 \\
\hline & \multicolumn{8}{|c|}{ Adjusted money income + Annuity on financial assets } \\
\hline All households & 20 & 30 & 56 & 100 & 166 & 266 & 383 & 143 \\
\hline \multicolumn{9}{|c|}{ Households with heads -- } \\
\hline Age less than 55 & 19 & 30 & 56 & 99 & 160 & 247 & 341 & 132 \\
\hline Age 55-64 & 21 & 32 & 68 & 127 & 218 & 361 & 579 & 191 \\
\hline \multirow[t]{2}{*}{ Age 65 and older } & 23 & 31 & 51 & 89 & 162 & 298 & 448 & 164 \\
\hline & \multicolumn{8}{|c|}{ Adjusted money income + Annuity on financial assets + Return on net home equity } \\
\hline All households & 20 & 31 & 57 & 100 & 164 & 261 & 373 & 141 \\
\hline \multicolumn{9}{|c|}{ Households with heads -- } \\
\hline Age less than 55 & 19 & 29 & 55 & 98 & 157 & 240 & 329 & 129 \\
\hline Age 55-64 & 22 & 36 & 71 & 128 & 217 & 355 & 561 & 190 \\
\hline Age 65 and older & 27 & 35 & 57 & 96 & 166 & 298 & 436 & 166 \\
\hline
\end{tabular}

Note: Calculations are performed using "equivalent" or household-size-adjusted incomes for each household. Entries show equivalent income measured as a percent of the median size-adjusted income under the indicated income definition.

Source: Authors' tabulations of 2001 March CPS file. The 2001 SCF file is used to derive imputations of DC pension wealth and financial wealth where needed. 
Table 5. Relative Income at Selected Points in the Income Distribution under Alternative Definitions of Income, by Age of Household Head: Survey of Consumer Finances, 2000

Median income $=100$

\begin{tabular}{|c|c|c|c|c|c|c|c|c|}
\hline & \multicolumn{7}{|c|}{ Percentile of income distribution } & \multirow{2}{*}{$\begin{array}{c}\text { Overall } \\
\text { Mean }\end{array}$} \\
\hline & 5 & 10 & 25 & 50 & 75 & 90 & 95 & \\
\hline & \multicolumn{8}{|c|}{ Money income } \\
\hline All households & 17 & 27 & 52 & 100 & 176 & 282 & 405 & 161 \\
\hline \multicolumn{9}{|c|}{ Households with heads -- } \\
\hline Age less than 55 & 17 & 26 & 54 & 104 & 176 & 276 & 394 & 157 \\
\hline Age 55-64 & 17 & 32 & 59 & 118 & 223 & 365 & 559 & 228 \\
\hline \multirow[t]{2}{*}{ Age 65 and older } & 20 & 26 & 42 & 76 & 139 & 248 & 360 & 131 \\
\hline & \multicolumn{8}{|c|}{ Money income + Return on net home equity } \\
\hline All households & 18 & 27 & 52 & 100 & 173 & 275 & 402 & 158 \\
\hline \multicolumn{9}{|c|}{ Households with heads -- } \\
\hline Age less than 55 & 16 & 26 & 51 & 100 & 169 & 270 & 389 & 151 \\
\hline Age 55-64 & 22 & 31 & 64 & 121 & 229 & 352 & 546 & 227 \\
\hline \multirow[t]{2}{*}{ Age 65 and older } & 22 & 29 & 49 & 87 & 154 & 249 & 359 & 141 \\
\hline & \multicolumn{8}{|c|}{ Money income + Retirees' estimated annuity on DC pension holdings } \\
\hline All households & 17 & 26 & 52 & 100 & 174 & 283 & 411 & 160 \\
\hline \multicolumn{9}{|c|}{ Households with heads -- } \\
\hline Age less than 55 & 16 & 26 & 53 & 102 & 172 & 270 & 386 & 154 \\
\hline Age 55-64 & 17 & 31 & 58 & 122 & 223 & 378 & 570 & 231 \\
\hline \multirow[t]{2}{*}{ Age 65 and older } & 19 & 25 & 42 & 79 & 148 & 276 & 412 & 141 \\
\hline & \multicolumn{8}{|c|}{ Adjusted money income + Annuity on financial assets } \\
\hline All households & 17 & 25 & 50 & 100 & 181 & 308 & 459 & 173 \\
\hline \multicolumn{9}{|c|}{ Households with heads -- } \\
\hline Age less than 55 & 16 & 24 & 50 & 100 & 171 & 279 & 404 & 156 \\
\hline Age 55-64 & 17 & 29 & 58 & 125 & 243 & 420 & 742 & 263 \\
\hline \multirow[t]{2}{*}{ Age 65 and older } & 19 & 27 & 45 & 88 & 191 & 370 & 567 & 195 \\
\hline & \multicolumn{8}{|c|}{ Adjusted money income + Annuity on financial assets + Return on net home equity } \\
\hline All households & 17 & 26 & 50 & 100 & 181 & 305 & 461 & 172 \\
\hline \multicolumn{9}{|c|}{ Households with heads -- } \\
\hline Age less than 55 & 16 & 24 & 49 & 97 & 169 & 275 & 404 & 153 \\
\hline Age 55-64 & 21 & 31 & 61 & 128 & 243 & 423 & 729 & 263 \\
\hline Age 65 and older & 22 & 29 & 52 & 98 & 200 & 367 & 578 & 202 \\
\hline
\end{tabular}

Note: Calculations are performed using "equivalent” or household-size-adjusted incomes for each household. Entries show equivalent income measured as a percent of the median size-adjusted income under the indicated income definition.

Source: Authors' tabulations of 2001 SCF file. 
Figure 1. Aggregate Household Income Estimated in the NIPA and in Two Household Surveys, 1988-2005

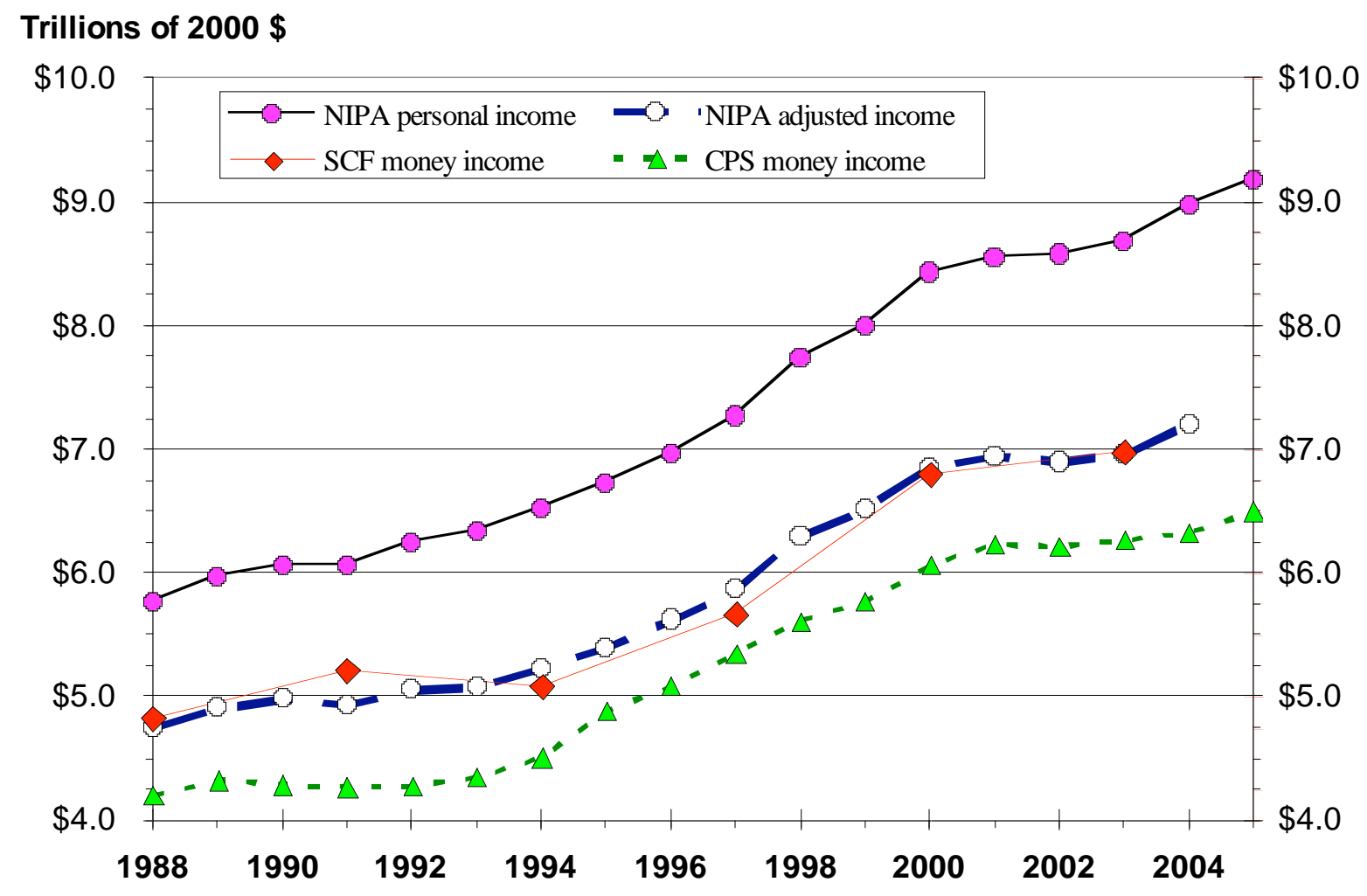

Source: Bureau of Economic Analysis and authors' tabulations of CPS and SCF public-use files for selected years. 
Figure 2. Military and Public Empoyee Pensions Reported on the CPS as a Percent of Equivalent Income Recorded in the NIPA, 1988-2005

\section{Percent of NIPA-recorded pensions}

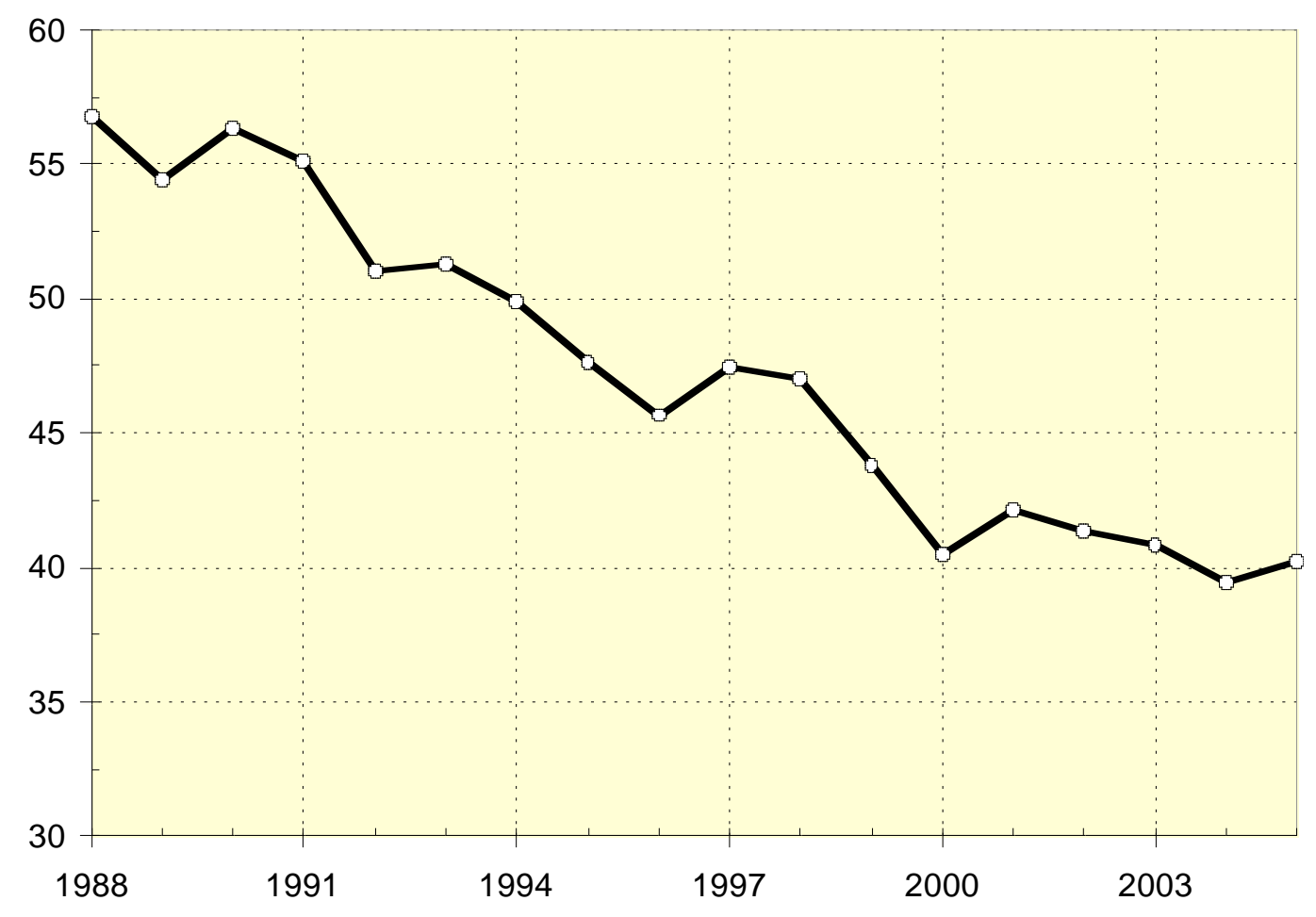

Sources: Bureau of Economic Analysis NIPA Table 6.11 and authors' tabulations of public-use Current Population Survey files for calendar years 1988-2005. 
Figure 3. Distribution of Equivalent Money Income in the CPS and SCF, 2000

\section{Natural logarithm of size-adjusted money income}

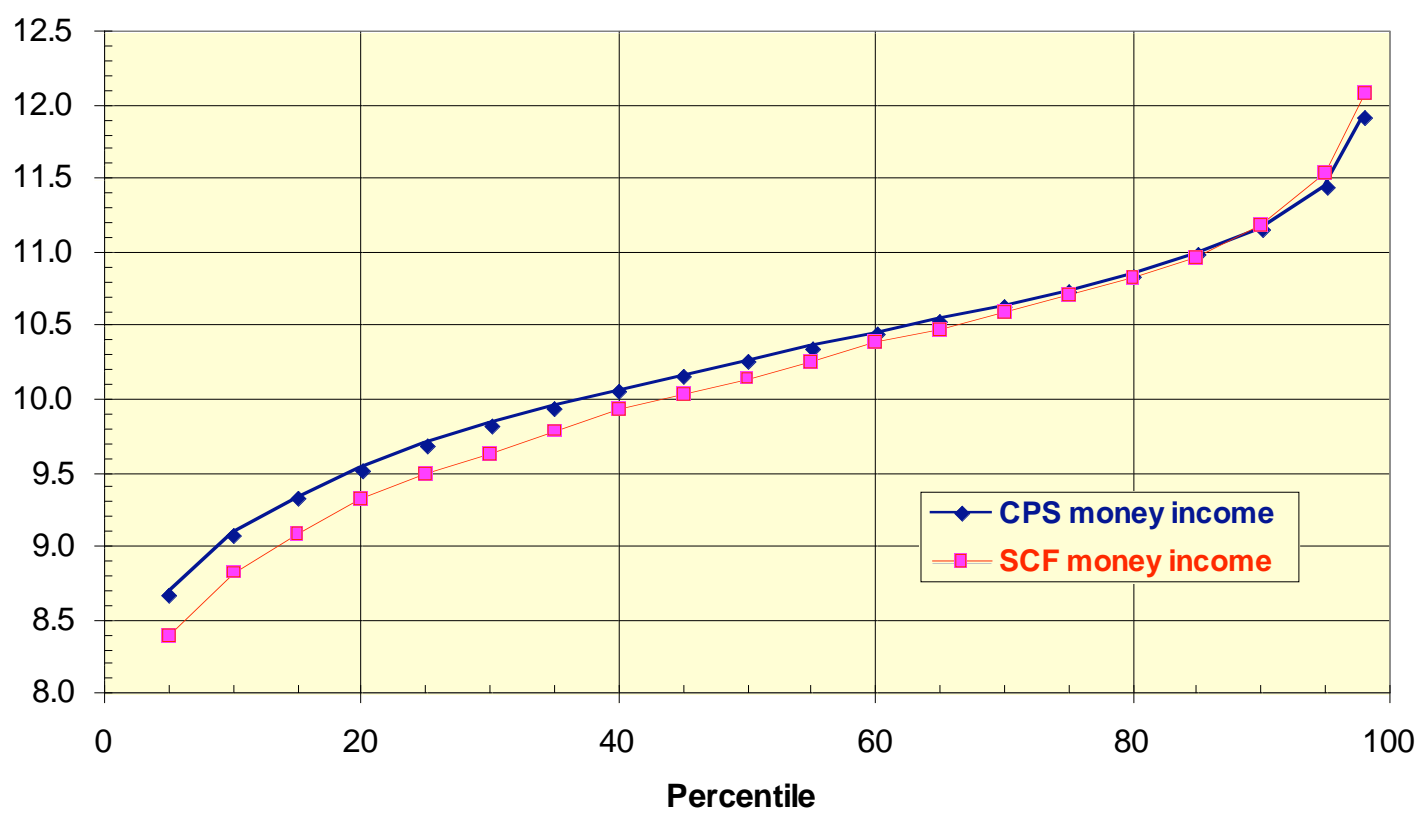

Note: Calculations are performed using "equivalent" or household-size-adjusted incomes for each household.

Source: Authors' tabulations of public-use 2001 March CPS and SCF files. 


\section{Figure 4. Impact of Including Return on Net Home Equity in Income Definition,}

by Age and Position in the Income Distribution, 1988-2000

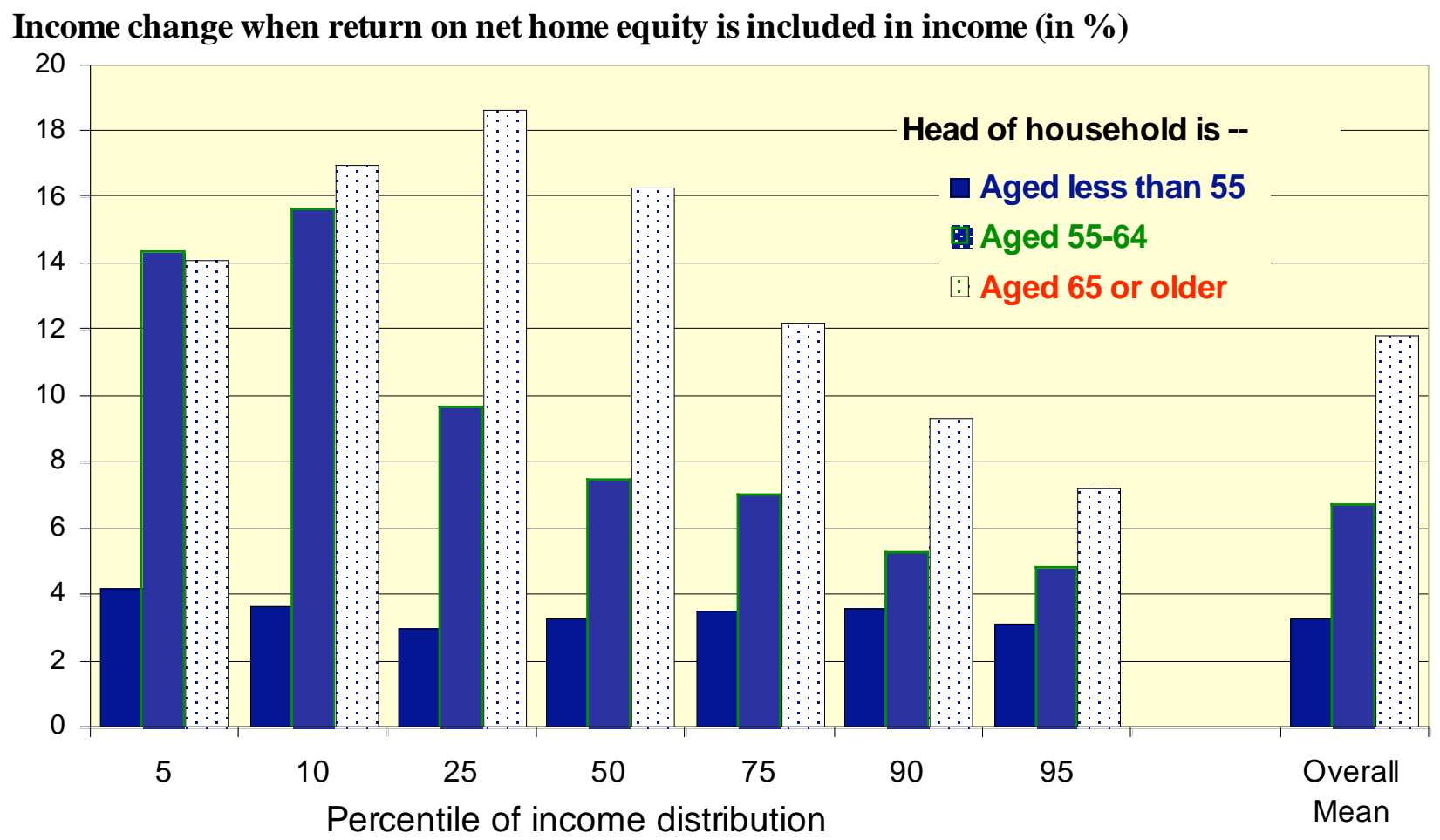

Note: Calculations are performed using "equivalent" or household-size-adjusted incomes for each household.

Source: Authors' tabulations of 1989, 1992, 1995, 1998, and 2001 public-use CPS files. 
Figure 5. Impact of Including Annuitized Income Flows from DefinedContribution Pensions in Income Definition, by Age and Position in the Income

\section{Distribution, 2000}
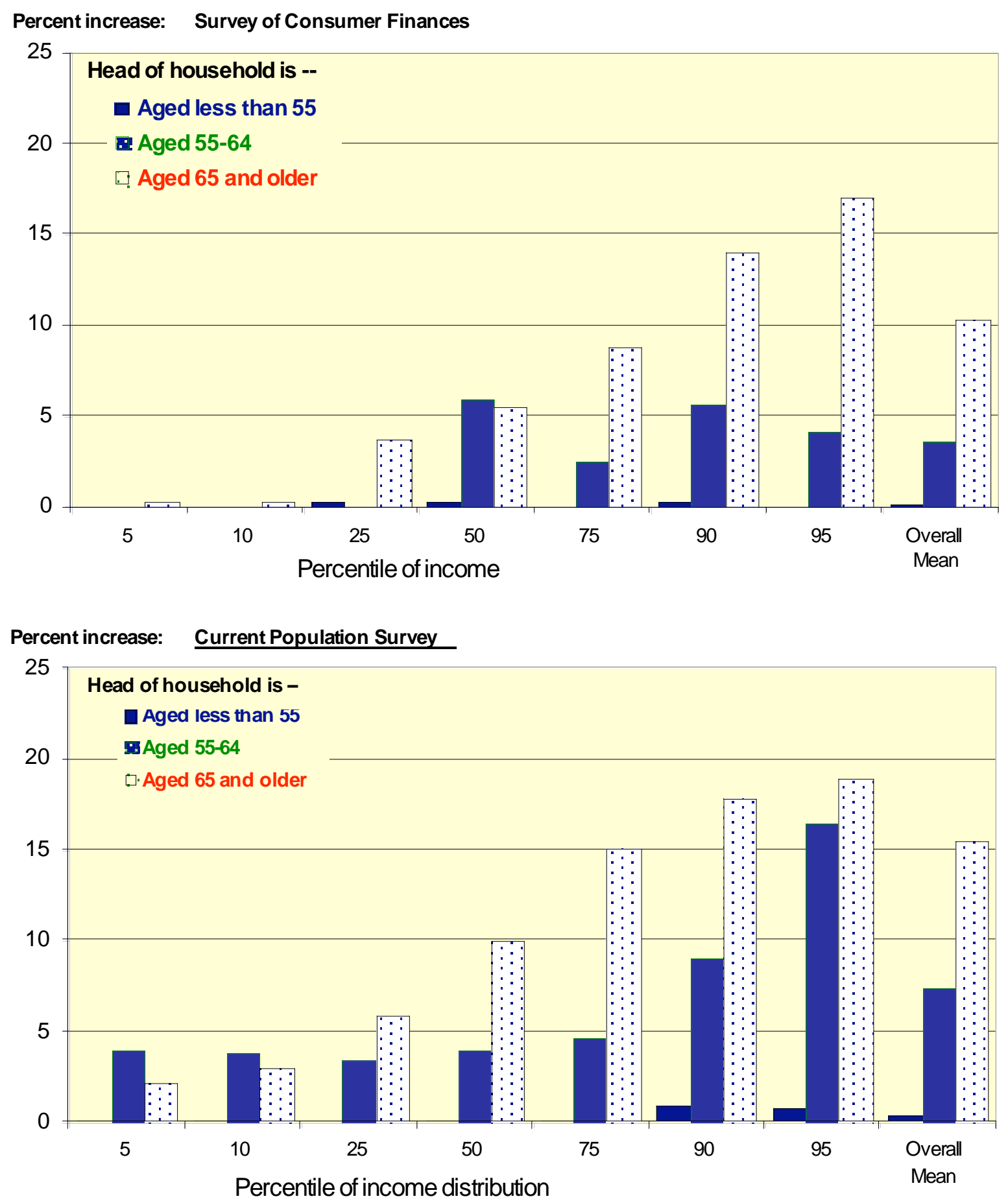

Note: Calculations are performed using "equivalent" or household-size-adjusted incomes for each household.

Source : Authors' tabulations of 2001 public-use CPS files and 2001 SCF files as explained in text. 
Figure 6. Impact of Including Annuitized Income Flows from All Financial Assets in Income Definition, by Age and Position in the Income Distribution, 2000
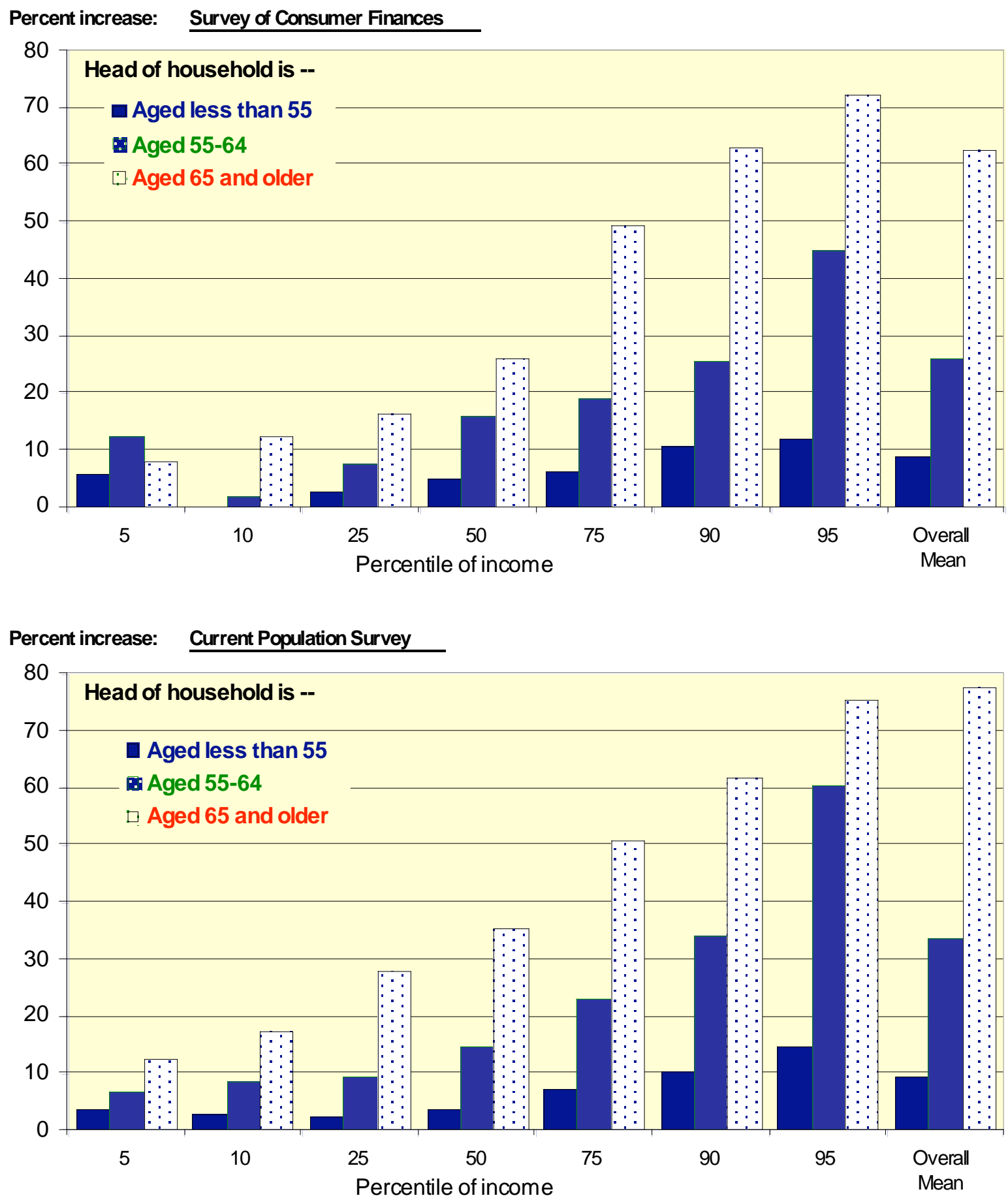

Note: Calculations are performed using "equivalent" or household-size-adjusted incomes for each household.

Source : Authors' tabulations of 2001 public-use CPS files and 2001 SCF files as explained in text. 
Figure 7. Impact of Including Annuitized Income Flows from Financial Assets and Return on Net Home Equity in Income Definition, by Age and Position in the Income Distribution, 2000
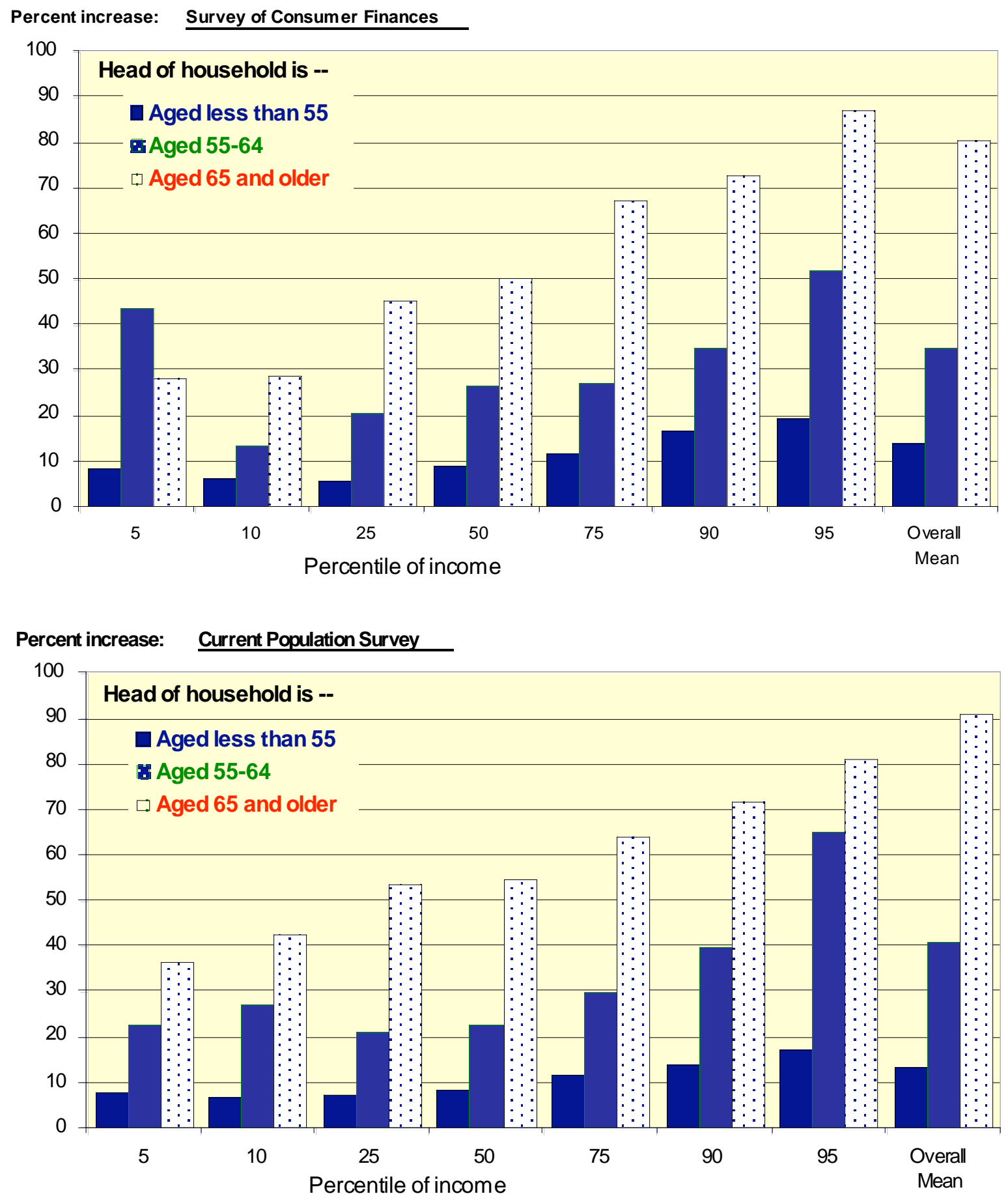

Note: Calculations are performed using "equivalent" or household-size-adjusted incomes for each household.

Source : Authors' tabulations of 2001 public-use CPS files and 2001 SCF files as explained in text. 
Figure 8. Impact of Including Annuitized Income Flows from Financial Assets and Return on Net Home Equity in Income Definition, by Age and Position in the Income Distribution: Current Population Survey File

\section{Natural logarithm of size-adjusted \\ money income}

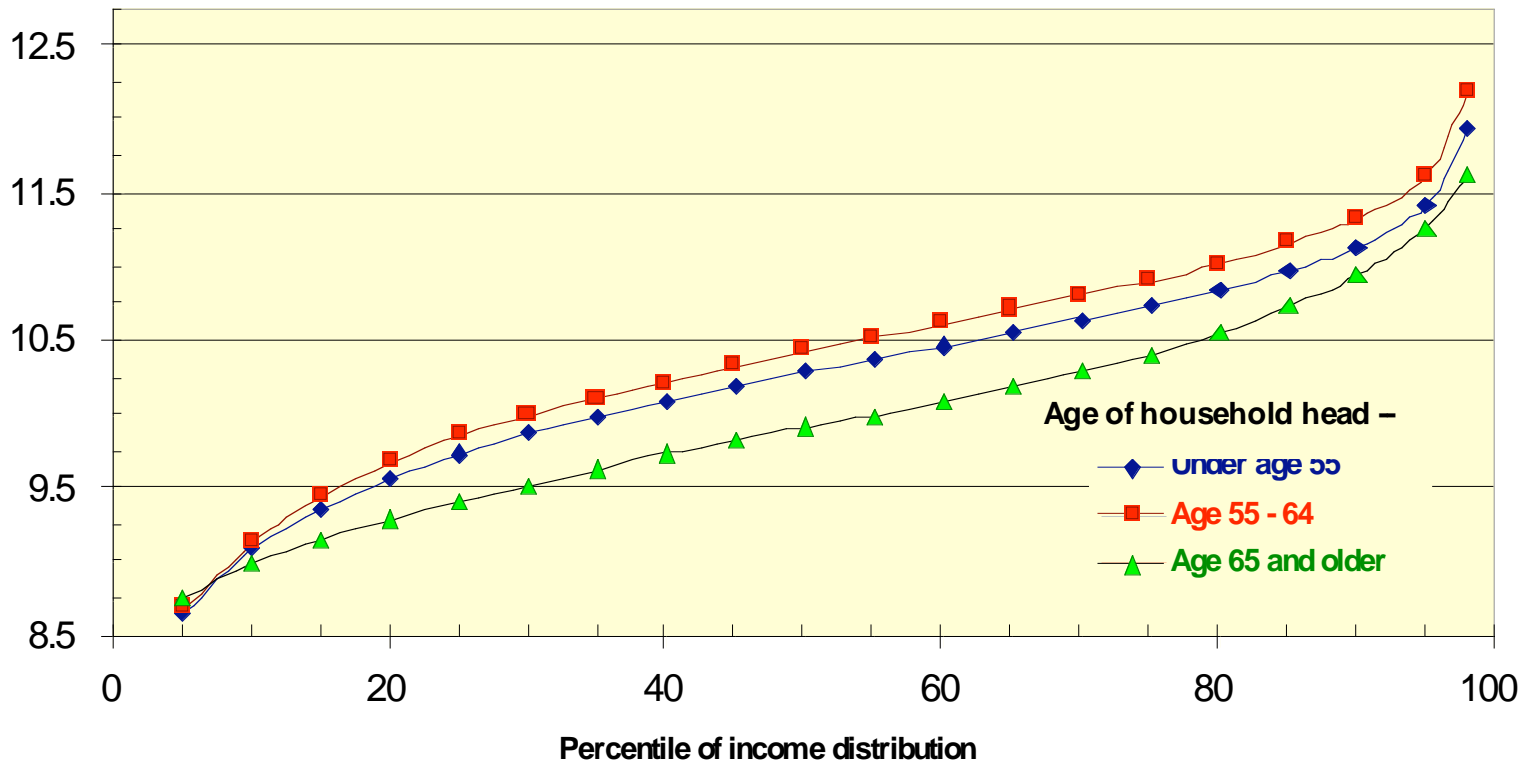

\section{Natural logarithm of size-ad justed income with annuity and return on net home equity}

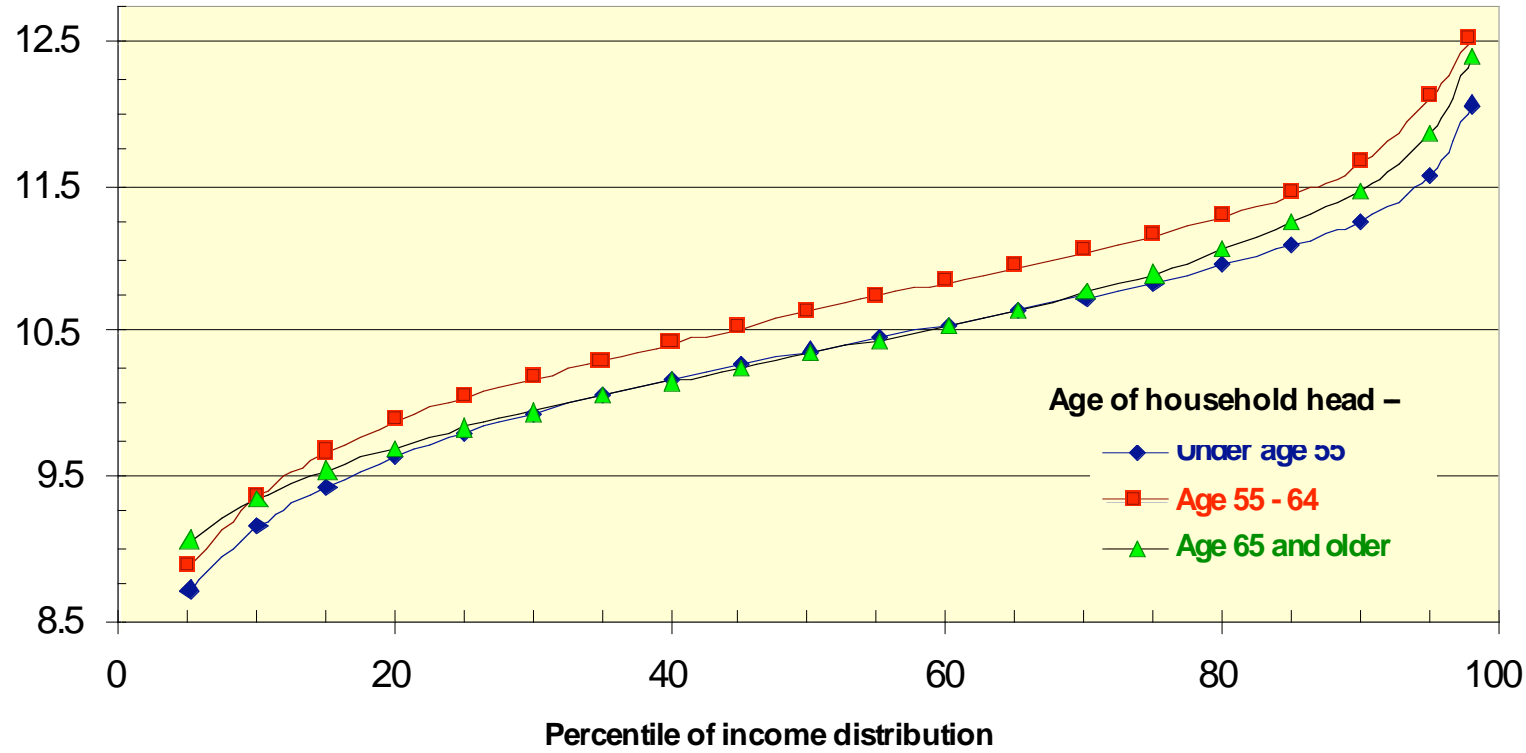

Note: Calculations are performed using "equivalent" or household-size-adjusted incomes for each household. The income data reflect annual incomes in 2000.

Source : Authors' tabulations of 2001 public-use CPS files and 2001 SCF files as explained in text. 
Figure 9. Impact of Including Annuitized Income Flows from Financial Assets and Return on Net Home Equity in Income Definition, by Age and Position in the Income Distribution: Survey of Consumer Finances File

\section{Natural logarithm of size-adjusted money income}

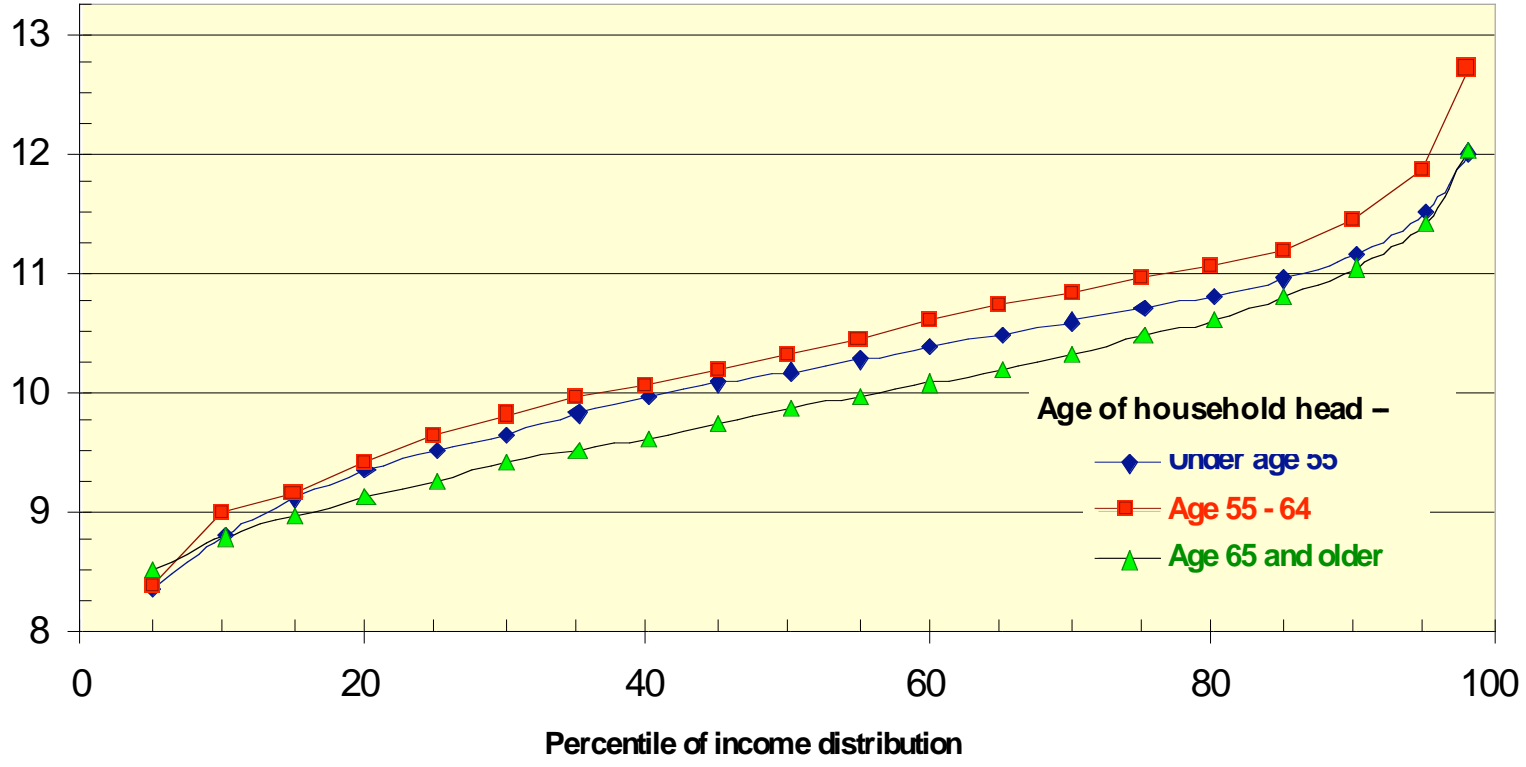

\section{Natural logarithm of size-ad justed income with annuity and return on net home equity}

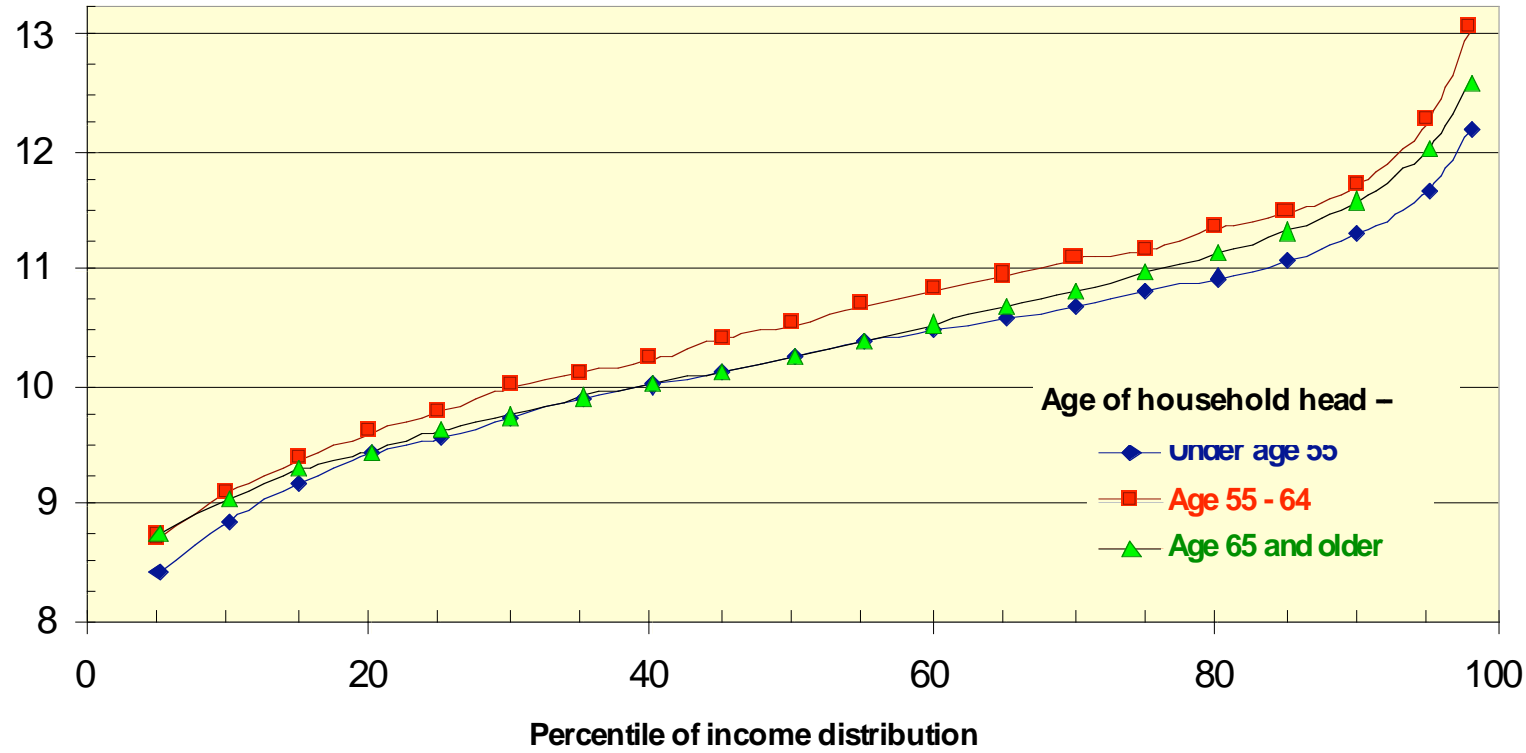

Note: Calculations are performed using "equivalent" or household-size-adjusted incomes for each household. The income data reflect annual incomes in 2000.

Source : Authors' tabulations of $2001 \mathrm{SCF}$ files as explained in text. 


\section{Appendix A \\ Evaluating the Survey Measures of Income}

The purpose of this appendix is to explain the methods that we used to benchmark the survey estimates of household income to the estimates of the national income accounts, and to report our estimates of their correspondence over the period of 1988-2005. ${ }^{1}$ There are several alternative sources of data that could be used as benchmarks of the survey estimates of particular types of income, such as income tax records, social security benefit payments, or employment records. We have chosen to rely on the national accounts because they provide consistent measures over time, and the Bureau of Economic Analysis has utilized all of the other available administrative data sources in trying to produce the most complete measures of income from current production. ${ }^{2}$ However, it is also important to recognize that the survey definitions of income do not always match the concepts used in the national income and product accounts (NIPAs). Our approach is to adjust the data of the national accounts to match the concepts of the March Current Population Survey (CPS), which in turn closely correspond to those used in the Survey of Consumer Finances (SCF). A summary of the adjustments is provided in table 1, where the data are grouped into five categories: (1) wage and salary income, (2) selfemployment income, (3) capital income, (4) transfers, and (5) retirement benefits.

Wage and Salary. The match between the NIPA and the CPS is straightforward for wage and salary income, except for the treatment of the self-employment income from incorporated businesses. The CPS obtains two measures of earned income - main job and all other work. ${ }^{3}$ In addition, the income for the main job can be identified for employees and the self-employed, with self-employed businesses being further divided into incorporated and unincorporated (sole proprietors, partnerships, and professional practice). The earnings of employees in their main job and income from other employers is classified as wage and salary income. In addition, it is important to note the main-job income of the self-employed in incorporated businesses is also included in wage and salary income. The rationale for including self-employment income from incorporated businesses in wage and salary income is that it would have been received by the worker as wage and salary income (possibly in order to avoid double taxation). Selfemployment income is limited to workers who report income from an unincorporated business. In the case of other earnings from self-employment, no distinction is made between incorporated and unincorporated, and it is all allocated to self-employment income.

The measure of wage and salary income in the CPS began to depart from the concept of the national accounts with the growth in popularity of sub-chapter S corporations. The $\mathrm{S}$ corporation has the limited liability advantages of general corporations, but the earnings are passed directly through to the owners' individual income tax returns without payment of the corporate income tax. Thus, the net income of such corporations is taxed only once, as income reported on individual income tax returns. The NIPAs include this net income as corporate profit and records the payments to individuals as dividend income. A problem arises in comparing

\footnotetext{
${ }^{1}$ The dates refer to the years in which the income was earned. Thus, the CPS data for 2005 were drawn from the March 2006 CPS.

${ }^{2}$ We benefited greatly from the material in Roemer (2000) and Ruser and others (2004).

${ }^{3}$ The questionnaire does not ever refer to wage and salary income. Instead, respondents are asked about income from jobs, and the classification as wages and salary is inferred from the answer to a question about type of job (employed or self-employed, unincorporated).
} 
CPS income and the NIPAs because the S-corporation income is reported in the CPS along with the earnings from other incorporated self-employed businesses as part of wage and salary income. In order to make the NIPA benchmark comparable to the income that is counted as "wage and salary income" on the CPS, we have obtained an estimate of S-corporation income and added it to NIPA wages and salary income.

It is not clear, however, how S-corporation income is actually reported by respondents in the CPS. On income tax returns, S-corporation income is reported on schedule $\mathrm{E}$ along with income from partnerships and other forms of property income. It is distinct from schedule C, which is generally used for business income and loss. Census interviewers for the CPS are instructed not to ask for data from income tax forms, but, if such data are offered by respondents, interviewers are instructed to classify schedule $\mathrm{E}$ income as business income rather than wage and salary income. In sum, it is not obvious how to derive an appropriate benchmark for income that is actually reported as "wage and salary income” in the CPS.

The classification of wage and salary income is straightforward for the SCF since there is a single question asking for this kind of income. Income from incorporated businesses is reported as the answer to other questions. Thus, the way wage and salary income is reported in the SCF seems fully consistent with the way it is treated in the NIPAs. The 2004 survey made specific reference to line 7 of IRS form 1040 in providing guidance to respondents about what they were expected to report as wages and salaries. Prior surveys made no specific reference to income tax forms.

Finally, we adjust the NIPA data for difference in the universe of persons covered by the two statistical sources. The CPS and the SCF exclude the income of individuals who live in institutions, on military bases, overseas, or who die before the interview date. We use the adjustment developed by Roemer and apply it as a ratio to the NIPA for years not covered by his study.

Self-employment income. The conceptual differences between the NIPA and the two surveys are small. The NIPA adjusts the depreciation claimed by businesses for the difference between economic and tax depreciation, and incorporates an inventory valuation adjustment. We remove both of those adjustments in reporting a NIPA-based estimate of self-employment income in table A1. The estimate of self-employment income for the CPS is the value reported as earnings for unincorporated businesses.

For the SCF, families are asked about income from a professional practice, business, or farm. ${ }^{4}$ In the 2004 survey, an important change was introduced when respondents were specifically directed to their form 1040 tax return -- in particular line 12, which refers to income reported on Schedule C, and line 18, farm income. A later question on net rent, trusts, or royalties directs the respondents to line 17 of the form 1040, which reports the net income recorded on Schedule E. Unfortunately, as noted above, Schedule E is used to report income from a wide range of sources -- including real estate, royalties, partnerships, S corporations, and trusts. Thus, large amounts of income that would be traditionally viewed as business income (i.e., self-employment income) are included within Schedule E. It is also apparent that the 2004 change in the questionnaire had a large effect on respondents. Business income declined from $\$ 653$ billion in the 2001 survey to $\$ 424$ billion in 2004. In contrast, the response to the question on rent, trusts and royalties jumped from $\$ 181$ to $\$ 429$ billion.

\footnotetext{
${ }^{4}$ We used the values for question x5704. The questionnaire explicitly excludes wage and salary income.
} 
Differences in the wording of the questions about income by category also create problems for the comparison of the SCF and the CPS. Given concerns about the distinction between incorporated and unincorporated businesses in the CPS, it might seem reasonable to combine business income with wages in an overall earned-income measure. However, the structure of the questions in the SCF - specifically, the reference to Schedule E - creates ambiguity in the distinction between business and capital income, suggesting a grouping of those two components.

Capital income. For purposes of adjusting the NIPA to the concepts of the CPS, we distinguish in table A1 among interest, dividends, and rental income. However, it is clear that the components should not be evaluated separately. When income passes through a financial intermediary, such as a mutual fund, it can easily be transformed from interest to dividend income. The most significant issues for aligning capital income in the national accounts and the surveys arise from the role of fiduciary accounts where funds are managed for households by third parties. Payments to these accounts are included as part of personal income in the national accounts. Yet individual households often have no specific knowledge of the income earned within the fiduciary accounts. Major examples are pension and life insurance funds. The CPS and SCF focus on cash income received by households, ignoring the buildup of assets within fiduciary accounts. In addition, the national accounts include nonprofits as part of the household sector, and impute to households an income receipt for services furnished without charge by financial institutions.

The specific table and line numbers of the NIPAs that reference the various elements of capital income are shown in table A1. The investment income received by nonprofit institutions, life insurance, and pension funds is not always allocated among its components of interest, dividends and rent in the national accounts; and we used a fixed allocation from other sources. That calculation, however, has no effect on the estimate of total capital income. In addition, we removed S-corporation dividends, which are combined with wage and salary income in the CPS. The most important aspect of the adjustments is that the exclusions greatly reduce the amount of capital income that is expected to be reported in the CPS and SCF surveys of cash income. Only about a fourth of the NIPA measure of interest income and one-third of dividend income is included within the concept employed by the CPS. In 2001, for example, only 28 percent of the $\$ 1,547$ billion of capital income in the national accounts translated over to the concepts of the CPS.

Transfers. Most government transfers of the CPS have their equivalents in the national accounts, and the detailed government accounts of the NIPAs makes the translation quite simple. Important exceptions are Medicare, Medicaid, and food stamps from the basic money income measure of the CPS. These payments count as transfer income in the NIPAs, but they are excluded from the CPS concept of money income because they are in-kind payments. In addition, the NIPAs have no counterparts to intra-household payments, such as child support, alimony, and inheritances. These items, which are included in the Census Bureau's concept of money income, are therefore excluded from the comparisons. The CPS asks far more detailed questions than the SCF about transfers. Since the SCF only asks about three broad categories, it is reasonable to expect a higher level of reported income on the CPS.

Retirement Income. The values reported for Old-Age, Survivors, and Disability insurance (OASDI) and railroad retirement reported in the NIPAs should align well with both surveys because the definitions are very similar. The only significant classification issue is to exclude Supplementary Security Insurance (SSI) from the retirement programs and include it as 
part of transfers. Prior to the 2001 survey, the SCF question on OASDI was ambiguous, and it appears that some respondents included SSI with OASDI.

We encountered more difficult problems in aligning the measures of pension income. The basic issues are discussed in depth by Woods (1996). Both the CPS and the SCF focus on benefit payments as the relevant income measure, and both define these as "regular payments," as opposed to lump-sum withdrawals. The NIPA accounts, in contrast, include pension funds within the household sector. Thus, employer contributions to pension and life insurance accounts and the capital income of the accounts are included as part of personal income, whereas payments out of the funds are regarded as an intra-household transaction and excluded.

Although benefit payments are not directly used in the NIPAs, the BEA prepares an addendum to table 6.11 that reports the payments. The data for benefit payments of government pension programs are readily available. For the private sector, however, the source of information is the Form 5500 reports that are filed with the IRS and processed by the Department of Labor. The summary of the 5500s lags by several years, and not all plans are included in the government's summary. Most importantly, plans administered by life insurance companies are not required to report benefit payments. The BEA does make adjustments that should result in complete coverage of private pension fund payments. Unfortunately, the NIPA measure includes lump-sum distributions that may or may not be rolled over into other retirement accounts. ${ }^{5}$ Ideally, the rollovers would be classified as a capital transfer and excluded from the measure of current personal income. Roemer (2000) and Ruser and others (2004) suggest that the lump-sum component can be approximated with the information of disbursements from definedcontribution plans, and they suggest excluding them, making no distinction between rollovers and payments that are retained by the recipients. Their suggestion, however, seems extreme in effectively ignoring defined-contribution pension plans as a source of retirement income.

The Statistics of Income (SOI), prepared by the Internal Revenue Service using data reported on income tax returns, is an alternative source for pension data. Individuals report both total and taxable pension and annuity income on lines 16a and 16b of the IRS Form 1040. In general, the receipt of pension income is reported on Form 1099R. Sabelhaus and Weiner (1999) suggest that rollovers into other tax-qualified plans are the primary source of the difference between total pension receipts (16a) and taxable pension income (16b). By rolling the payments over, individuals can defer the income tax and avoid a 10 percent penalty if they are under age 591/2. Beginning in 1992, lump-sum disbursements also became subject to a 20 percent withholding tax that could be avoided by having the employer directly transfer the funds to the new plan. While many small distributions are not rolled over, 70-80 percent of the dollar amount is moved to other tax-deferred accounts (Sabelhaus and Weiner, 1999; and Moore and Muller, 2002). We opted to use the SOI measure of taxable pension income plus railroad retirement from the NIPA as our benchmark measure. ${ }^{6}$

There is also considerable ambiguity as to what is being recorded in the CPS and the SCF surveys. For the CPS, we relied on Unicon data files. These report pension income as the sum of three components: survivor, disability, and retirement benefits. However, we adjusted those

${ }^{5}$ The BEA data also specifically exclude IRAs, Keogh plans (employer) and Simplified Employee Plans (SEPS).

${ }^{6}$ Recent work using the 1099R information to estimate retirement income for 1997-2002 has been done by David Lenze of the Bureau of Economic Analysis. His estimates are considerably higher than the taxable amount that we have used. 
aggregates to move some payments under workers' compensation and black lung payments to transfers. For the SCF, we used the responses to a question about pension and disability payments, which explicitly excludes IRA and Keogh plans. We make no distinction in our tabulations between retirement and disability. 


\section{Table A1. Conversion of National Accounts Data to the Concepts of Census Bureau Money Income}

\begin{tabular}{|c|c|c|c|}
\hline \multicolumn{4}{|c|}{ Billions of Dollars } \\
\hline Categories & NIPA tables and line numbers & $\begin{array}{c}\text { NIPA } \\
\text { Values }\end{array}$ & $\begin{array}{l}\text { Adjusted } \\
\text { Values }\end{array}$ \\
\hline \multicolumn{4}{|l|}{ Earnings } \\
\hline \multirow[t]{5}{*}{ Wages } & Wage and salary disbursements (Table 2.1, L3) & 4,943 & 5,076 \\
\hline & S-corporation net income from Spring Statistics of Income, various years & & \\
\hline & (http://www.irs.gov/taxstats/bustaxstats/article/0,,id=96405,00.html) & 188 & \\
\hline & Less: & 55 & \\
\hline & Out of universe (Roemer) & 55 & \\
\hline \multirow[t]{5}{*}{ Self Employment Income } & $\begin{array}{l}\text { Proprietors' income with IVA and CCAdj (Table 1.12, L9) } \\
\text { Less: }\end{array}$ & 772 & 676 \\
\hline & Capital consumption adjustment, farm (Table 1.12, L34) & -6 & \\
\hline & Inventory valuation adjustment, nonfarm (Table 1.12, L37) & 1 & \\
\hline & Capital consumption adjustment, nonfarm (Table 1.12, L38) & 94 & \\
\hline & Out of universe (Roemer) & 6 & \\
\hline \multirow{14}{*}{$\begin{array}{l}\text { Capital Income } \\
\text { Interest income }\end{array}$} & & 1,547 & 429 \\
\hline & Personal Interest Income (Table 2.1, L14) & 1,011 & 243 \\
\hline & Less: & & \\
\hline & Interest share of investment income received by nonprofit institutions or retained by fiduciaries (Table 7.19 , & & \\
\hline & (25) & $\begin{array}{l}70.6^{*}(28.8 /(2+38.6)) \\
(445.5-\end{array}$ & \\
\hline & Interest share of investment income of life insurance carriers and pension plans (Table 7.19, L6) less Imputed & $205.9)^{*}(104.1 /(104.1+$ & \\
\hline & interest received by households from life insurance carriers (Table 7.11, L63). ${ }^{2}$ & 19.5)) & \\
\hline & Imputed interest received from banks, credit agencies, and investment companies (Table 7.11, L62) & 168 & \\
\hline & Imputed interest received from life insurance carriers (Table 7.11, L63) & 206 & \\
\hline & Imputed interest received from property and casualty insurance companies (Table 7.11, L64) & 12 & \\
\hline & Imputed interest received by nonprofit institutions (Table 7.11, L65) & 1 & \\
\hline & Monetary interest received by publicly administered government employee retirement plans (Table 7.11, L33) & 104 & \\
\hline & Compiled Money Market Interest Earnings & 15 & \\
\hline & Out of universe (Roemer) & 10 & \\
\hline \multirow[t]{9}{*}{ Dividends } & Dividends received by persons (Table 7.10, L12) & 369 & 115 \\
\hline & Compiled Money Market Interest Earnings & 15 & \\
\hline & Less: & & \\
\hline & $\begin{array}{l}\text { Dividend share of investment income received by nonprofit institutions or retained by fiduciaries (Table } 7.19 \text {, } \\
\text { L7). }{ }^{1}\end{array}$ & $70.6^{*}(9.7 /(2+38.6))$ & \\
\hline & S-corporation net income from Spring Statistics of Income, various years & 188 & \\
\hline & Dividend share of investment income of life insurance carriers and pension plans (Table 7.19, L6) less Imputed & $\begin{array}{c}(445.5- \\
205.9)^{*}(19.5 /(104.1+1\end{array}$ & \\
\hline & interest received from life insurance carriers (Table 7.11, L63). ${ }^{2}$ & $\begin{array}{l}9.5)) \\
905.9)(19.104 \\
0\end{array}$ & \\
\hline & Dividends received by publicly administered government employee retirement plans (Table 7.10, L13) & 20 & \\
\hline & Out of universe (Roemer) & 7 & \\
\hline
\end{tabular}


Table A1. Conversion of National Accounts Data to the Concepts of Census Bureau Money Income (continued)

Billions of Dollars

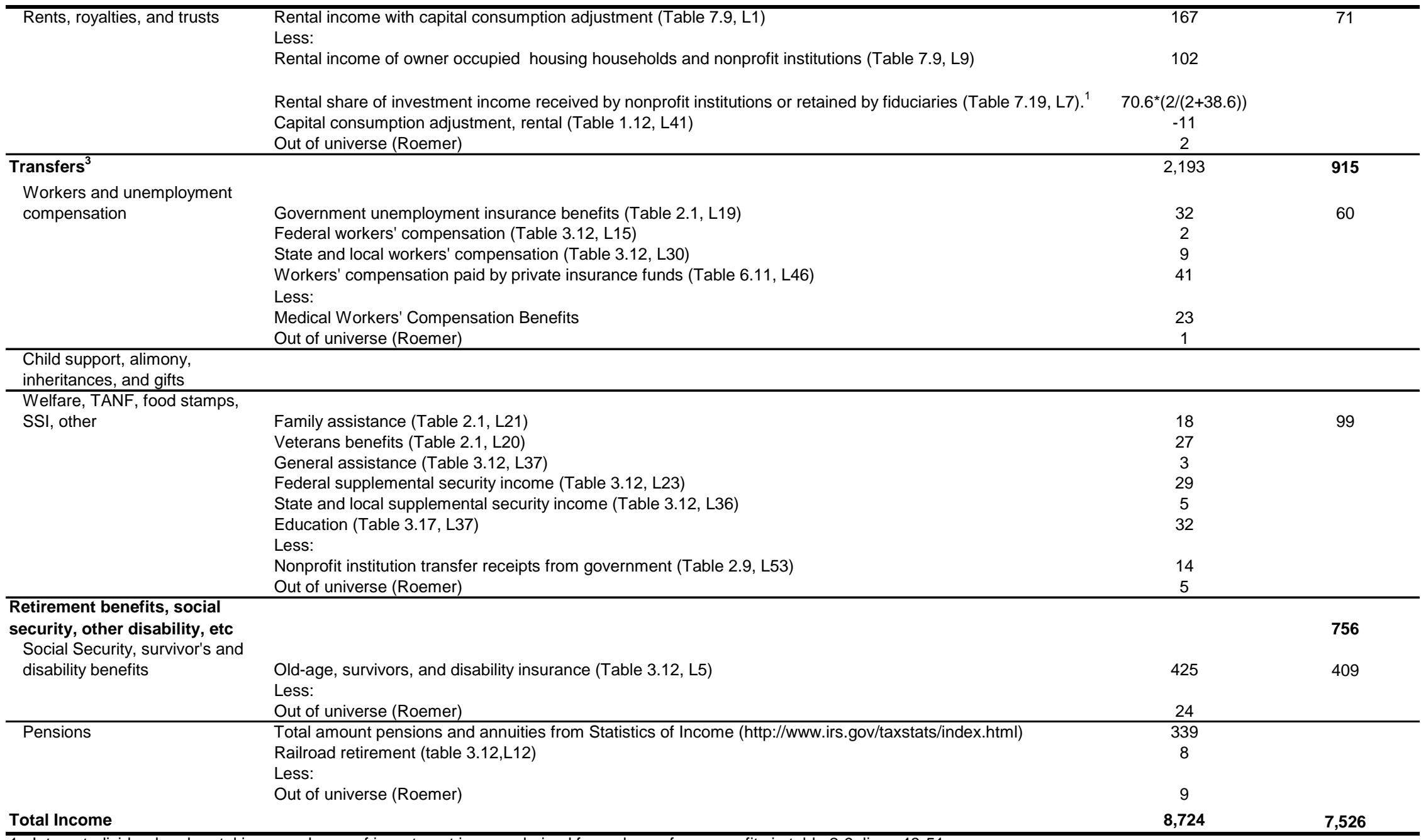

1. Interest, dividend and rental income shares of investment income derived from shares for nonprofits in table 2-9, lines 48-51.

2. Interest and dividend shares of investment income of private pension plans derived from interest and dividends of government plans (7.10,line 13 and 7.11 , line 33$)$

3. Major excluded items are noncash elements of Medicare, Medicaid, and the food stamp program. In addition, pensions are recorded within the CPS on the basis of benefits paid. 
Table A2. Variable Codes Used From the Current Population Survey and Survey of Consumer Finances

\begin{tabular}{|c|c|c|}
\hline & CPS & SCF \\
\hline Wage and Salary & HINCWS & X5702 \\
\hline Self Employment Income & HINCSE, HINCFR & X5704 \\
\hline \multicolumn{3}{|l|}{ Capital Income } \\
\hline Interest income & HINCIN & X5706, X 5708 \\
\hline Dividends & HINCDI & X5710 \\
\hline Rents, royalties, and trusts & HINCRN & X5714 \\
\hline \multicolumn{3}{|l|}{ Transfers } \\
\hline Workers and unemployment compensation & $\begin{array}{l}\text { HINCWC, HINCUC } \\
\text { HINCCS, HINCAL, }\end{array}$ & X5716 \\
\hline Child support, alimony, inheritances, and gifts & $\begin{array}{c}\text { HINCFA } \\
\text { HINCPA, HINCVP, }\end{array}$ & $\mathrm{X} 5718$ \\
\hline Welfare, TANF, SSI, other & HINCED, HINCSP & X5720 \\
\hline Retirement benefits & & X5722 \\
\hline Social Security & $\begin{array}{l}\text { HINCRE, HINCSI, } \\
\text { HINCDS }\end{array}$ & $\begin{array}{c}x 5306, x 5311 \\
x 5318, x 5326, \\
x 5334, x 5418, \\
x 5426, x 5434, \\
x 6804\end{array}$ \\
\hline Other income & HINCOTH & X5724 \\
\hline
\end{tabular}

Source: The variable names for the CPS are those assigned in the Unicon Research Corporation compilation of the March supplement. The codes for the SCF remain the same from one survey to another.

1. The pension variables from the CPS were redone to move Workers compensation and Black Lung payments into the transfer category. 
Table A3. Comparable Measures of Income: National Accounts, Current Population Survey, and the Survey of Consumer Finances, 1988-2003

National Income and Product Accounts

Adjusted to CPS definitions, Billions of dollars

\begin{tabular}{|c|c|c|c|c|c|c|}
\hline & 1988 & 1991 & 1994 & 1997 & 2000 & 2003 \\
\hline Earnings & 2,769 & 3,189 & 3,739 & 4,524 & 5,639 & 5,956 \\
\hline Wages & 2,426 & 2,792 & 3,196 & 3,835 & 4,776 & 5,056 \\
\hline Self Employment Income & 310 & 357 & 451 & 536 & 664 & 686 \\
\hline S-corporation Income & 33 & 40 & 92 & 153 & 199 & 214 \\
\hline Capital Income & 308 & 377 & 305 & 314 & 367 & 377 \\
\hline Interest income & 211 & 249 & 164 & 149 & 197 & 171 \\
\hline Dividends & 68 & 91 & 87 & 103 & 105 & 147 \\
\hline Rents, royalties, and trusts & 29 & 37 & 54 & 62 & 65 & 59 \\
\hline Transfers & 430 & 554 & 650 & 744 & 853 & 1,019 \\
\hline Workers and unemployment compensation & 31 & 51 & 50 & 45 & 47 & 81 \\
\hline Child support, alimony, inheritances, and gifts & - & - & - & - & - & - \\
\hline Welfare, TANF, SSI, other & 56 & 68 & 85 & 87 & 94 & 111 \\
\hline Retirement benefits & 343 & 435 & 515 & 612 & 712 & 827 \\
\hline Social Security, survivor's and disability benefit؛ & 202 & 256 & 302 & 344 & 378 & 445 \\
\hline Pensions & 142 & 179 & 213 & 268 & 334 & 382 \\
\hline Other income & N/A & N/A & N/A & N/A & N/A & N/A \\
\hline
\end{tabular}

Current Population Survey, March Supplement, billions of dollars

\begin{tabular}{|c|c|c|c|c|c|c|}
\hline & 1988 & 1991 & 1994 & 1997 & 2000 & 2003 \\
\hline Earnings & 2,481 & 2,816 & 3,215 & 4,084 & 4,991 & 5,434 \\
\hline Wages & 2,294 & 2,603 & 3,007 & 3,781 & 4,647 & 5,080 \\
\hline Self Employment Income & 186 & 213 & 208 & 303 & 344 & 354 \\
\hline Capital Income & 211 & 235 & 222 & 339 & 338 & 295 \\
\hline Interest income & 143 & 156 & 127 & 190 & 189 & 148 \\
\hline Dividends & 36 & 43 & 54 & 95 & 103 & 89 \\
\hline Rents, royalties, and trusts & 32 & 36 & 41 & 54 & 47 & 58 \\
\hline Transfers & 409 & 509 & 600 & 662 & 737 & 883 \\
\hline Workers and unemployment compensation & 21 & 37 & 36 & 29 & 29 & 53 \\
\hline Child support, alimony, inheritances, and gifts & 20 & 23 & 30 & 32 & 41 & 44 \\
\hline Welfare, TANF, SSI, other & 48 & 63 & 75 & 77 & 81 & 96 \\
\hline Retirement benefits & 319 & 386 & 460 & 525 & 586 & 691 \\
\hline Social Security & 182 & 219 & 273 & 312 & 350 & 405 \\
\hline Pensions & 137 & 167 & 187 & 214 & 236 & 286 \\
\hline Other income & 5 & 6 & 10 & 11 & 6 & 7 \\
\hline Total Income & 3,106 & 3,566 & 4,047 & 5,096 & 6,073 & 6,620 \\
\hline
\end{tabular}


Table A3. Comparable Measures of Income: National Accounts, Current Population Survey, and the Survey of Consumer Finances, 1988-2003 (continued)

Survey of Consumer Finances

Billions of dollars

\begin{tabular}{|c|c|c|c|c|c|c|}
\hline & 1988 & 1991 & 1994 & 1997 & 2000 & 2003 \\
\hline Earnings & 2,761 & 3,248 & 3,674 & 4,446 & 5,650 & 5,787 \\
\hline Wages & 2,463 & 2,791 & 3,265 & 3,870 & 4,997 & 5,363 \\
\hline Self Employment Income & 298 & 457 & 409 & 576 & 653 & 424 \\
\hline Capital Income & 359 & 362 & 375 & 386 & 484 & 697 \\
\hline Interest income & 175 & 162 & 152 & 139 & 195 & 161 \\
\hline Dividends & 66 & 69 & 100 & 98 & 108 & 107 \\
\hline Rents, royalties, and trusts & 118 & 130 & 123 & 149 & 181 & 429 \\
\hline Transfers & 369 & 421 & 474 & 520 & 619 & 846 \\
\hline Workers and unemployment compensation & 13 & 25 & 17 & 14 & 15 & 32 \\
\hline Child support, alimony, inheritances, and gifts & 19 & 21 & 20 & 25 & 28 & 31 \\
\hline Welfare, TANF, SSI, other & 31 & 32 & 35 & 23 & 19 & 32 \\
\hline Retirement benefits & 307 & 343 & 402 & 458 & 556 & 752 \\
\hline OASDI & 157 & 173 & 196 & 232 & 322 & 393 \\
\hline Pensions & 150 & 170 & 207 & 226 & 235 & 358 \\
\hline Other income & 72 & 322 & 39 & 42 & 51 & 43 \\
\hline Total Income & 3,562 & 4,353 & 4,563 & 5,394 & 6,805 & 7,373 \\
\hline
\end{tabular}

Source: compiled by authors as explained in text. S-corporation income is combined with wages from the NIPAs for comparisons to the CPS and with self-employment income for comparisons with the SCF. 


\section{Appendix B Imputing Wealth Holdings and Annuity Income Flows to CPS Households}

For both the SCF and CPS, we calculate estimates of annuity income flows out of wealth ("annuitized wealth") to measure its impact on the income positions of aged and nonaged Americans. However, before we can annuitize wealth for respondents in the CPS sample, we must impute wealth holdings to each household, since the CPS files only include information on income and ownership of a dwelling. We impute four measures of each household's wealth: net home equity in a primary residence, DC pension wealth, financial wealth, and total wealth excluding net home equity in a primary residence. We derive these imputations using wealth information supplied by respondents to the SCF.

Net home equity imputations. The CPS public-use files contain an estimate for each home-owning household of the return on net equity in a principal residence. However, the value of net home equity used to calculate this return is not included on the file. Therefore, we impute a value for net home equity from the SCF. SCF households are first ranked by their net home equity on the SCF, and CPS households are ranked by their return to net home equity on the CPS. Within each survey, households who own their homes and report positive net home equity (or are imputed a positive value of return on net home equity) are divided into three hundred equal-size subpopulations, ranked from lowest to highest depending on net home equity or return on net home equity. The weighted mean within each one of these 300 groups on the SCF is calculated and then assigned to households within the corresponding group on the CPS. The same procedure is used for households reporting negative net home equity (or return to net home equity), except that twenty equally-weighted cells are used instead of three hundred. (There are many fewer households with negative net home equity than there are with positive home equity.) Finally, non-homeowners on the CPS are assigned a zero value for net home equity.

Statistical imputation and adjustments in the SCF dataset before imputation. Wealth, financial wealth, and pension wealth are imputed onto CPS households using the responses of similar but randomly selected households in the SCF. The imputation is done using a statistical matching procedure similar to hot decking. Hot decking is ordinarily used to impute missing data in the event of survey non-response. ${ }^{1}$ This type of problem arises when a respondent fails to give a valid answer to a survey question. In a standard hot decking imputation, respondents in the sample are stratified into cells defined by several categorical variables. Within each cell, a donor (that is, an observation in the survey file who has a valid response) is randomly selected to represent each identified mis-reporter in the file. In most cases, the procedure is carried out with the proviso that no donor can be selected more than a specified number of times. Once a donor and mis-reporter are matched, the valid responses of the donor are copied over to the misreporter (or non-respondent). In the event that a donor is not available in the exact cell in which the mis-reporter is a member, the procedure advances to succeeding higher level cells until a donor is found. In our case, donors are randomly selected from appropriately defined cells in the SCF file to supply wealth information for households in the CPS file.

However, a weighting issue with the SCF dataset must first be resolved before these imputations can be performed. Household weights on the CPS are fairly uniformly distributed and not terribly unequal among households in the file. The same does not hold true for

\footnotetext{
${ }^{1}$ For an example and explanation of hot decking, see Toder and others (1999).
} 
observations in the SCF file, however. Since the SCF over-samples high-wealth households, it is possible for the wealth of a high-wealth household having a small weight on the SCF to be imputed to a number of CPS households which have large weights. Therefore, in order to ensure that the sum of wealth on both the SCF and CPS will be roughly equal, the number of observations and household weights of households in the SCF file must be adjusted before statistical matching is performed.

First, households are ranked by their weights in ascending order and then assigned to one of twenty equal-sized groups. Next, the average weight is calculated within each of these groups. Our goal is for the average weight in each group to equal the average weight in the group which has the smallest average weight. This is done by running through the observations in each category repeatedly and replicating them until the average of the weights of the replicated observations is equal to the average weight of observations in the group that has the smallest average weight. The sum of the weights remains unchanged because the new weight is divided by the number of replications performed. For example, if an observation must be replicated five times, the weights of all five observations will all be equal to the original weight divided by five. Our original 2001 SCF dataset had 22,210 household observations; our "matching” SCF file, with replications, contained nearly 10 million observations. The large number of replicated observations reflects the huge disparity in the SCF file in the weights of observations in that file.

Imputing wealth from the SCF to the CPS. Before imputation is performed, households in the SCF and CPS are sorted by various characteristics (or key variables) to ensure that wealth from an SCF household is matched to a similar household on the CPS. Households in both surveys are first divided into nine age groups: under 25, 25-34, 35-44, 45-49, 50-54, 55-59, 60 64, 65-69, and 70 and over. Within each age group, observations are then allocated to three subgroups depending on the level of their reported income from capital. The 5 percent of households within both surveys reporting the highest capital income in each age group are placed in the high capital income category. Within the SCF, all households reporting zero capital income are placed in the low capital income category. Households on the CPS with zero capital income are placed in the low capital income category and then additional households with very low levels of reported capital income are added to this category until the percentage of households in the low category matches the percentage of SCF households in that category. All remaining households in both surveys, which include households with negative capital income, are placed in the middle capital income category. After households are divided up using this procedure, both the CPS and SCF show the same percentage of households in each category. Within the first seven age groups (head under 65), households are further divided into thirds according to the level of their labor income. Within the highest two age groups (65 and over), households are divided into thirds of social security income.

Taking all of these characteristics into account, households from both surveys are divided into 81 groups ( 9 age categories multiplied by 3 capital income categories multiplied by 3 labor income or social security income categories). Households from the CPS are grouped together with households from corresponding groups in the SCF and then sorted randomly. Each CPS household is imputed the value for DC pension wealth, financial wealth and wealth excluding net home equity from the SCF household immediately preceding it.

Calculating annuity income flows. For both the SCF and CPS, we construct estimates of annuity income flows for up to two categories of wealth: (1) DC pension wealth, and (2) 
financial wealth. For these wealth categories, we calculate potential annuity income flows for each household.

The market price that an individual pays for annuities depends on four factors: the expected remaining life span of the insured person when he or she purchases an annuity, the amount of adverse selection among people buying annuities, the customer's decision to buy a single-life or joint-survivor pension, and the market rate of interest at which insurance companies can invest their reserves. We assume there is no adverse selection in the population buying annuities. To calculate an annuity income flow we assume that a single household head converts his or her wealth holdings into a single-life annuity that is fixed in nominal terms. Male or female life tables are used to calculate annuity payments, depending on the sex of the household head. If the household head is a spouse in a married couple, we assume wealth holdings are converted into a joint-survivor life annuity in which a single surviving spouse receives 70 percent of the annuity payment received when both spouses are alive. ${ }^{2}$ The insurance company selling the annuity bases its price on the expected mortality experience of American men and women, using 2003 mortality tables published by the Social Security Actuary (http://www.ssa.gov/OACT/STATS/table4c6.html).

We used two different interest rates in calculating the annuity income flow from a particular wealth holding. The most suitable interest rate is the one an insurance company can expect to earn on its reserves, so it should reflect the return on a comparatively safe asset. First, we used the average bond yield of corporate AAA securities and Treasury constant-maturity 10year securities. In 2000 this average interest rate was 6.83 percent. It represents a comparatively safe rate of return on intermediate term bonds. We also calculated annuities using the riskless rate of return on intermediate term bonds. An approximation to this interest rate is the nominal return on newly issued U.S. Treasury I-bonds (essentially savings bonds indexed to inflation). In 2000 the average nominal interest rate on newly issued I-bonds was 5.74 percent.

Other adjustments to income. When we add annuity income flows from a particular asset class to household incomes we must also exclude reported income amounts on the CPS or SCF if they are derived from this asset class. For example, if we add the estimated annuity flow from a household's financial assets, we must exclude any interest or dividend payments that are reported as current income. Without making this adjustment in households' current income reports we would be double counting the actual or potential income that is derived from the asset.

2 This survivor benefit was selected so that the household-size-adjusted annuity of the survivor would be identical to the household-size adjusted annuity of the couple. 


\section{RECENT WORKING PAPERS FROM THE}

\section{CENTER FOR RETIREMENT RESEARCH AT BOSTON COLLEGE}

The Role of Governance in Retirement Investments: Evidence from Variable Annuities

Richard Evans and Rudiger Fahlenbrach, October 2007

A New Approach to Raising Social Security's Earliest Eligibility Age

Kelly Haverstick, Margarita Sapozhnikov, Robert Triest, and Natalia Zhivan, October 2007

What Makes Retirees Happier: A Gradual or 'Cold Turkey' Retirement?

Esteban Calvo, Kelly Haverstick, and Steven A. Sass, October 2007

Why Do Married Men Claim Social Security Benefits So Early? Ignorance, Caddishness, or Something Else?

Steven A. Sass, Wei Sun, and Anthony Webb, October 2007

Measurement Error in Earnings Data in the Health and Retirement Study

Jesse Bricker and Gary V. Engelhardt, October 2007

Evaluating the Advanced Life Deferred Annuity - An Annuity People Might Actually Buy

Guan Gong and Anthony Webb, September 2007

Population Aging, Labor Demand, and the Structure of Wages

Margarita Sapozhnikov and Robert K. Triest, September 2007

Work at Older Ages: Is Raising the Early Retirement Age an Option for Social Security Reform?

John A. Turner, August 2007

The Labor Supply of Older Americans

Alicia H. Munnell and Steven A. Sass, May 2007

Why Do Japanese Workers Remain in the Labor Force So Long?

John B. Williamson and Masa Higo, May 2007

All working papers are available on the Center for Retirement Research website (http://www.bc.edu/crr) and can be requested by e-mail (crr@bc.edu) or phone (617-552-1762). 